\title{
Quercetin: A Bioactive Compound Imparting Cardiovascular and Neuroprotective Benefits: Scope for Exploring Fresh Produce, Their Wastes, and By-Products
}

\author{
Irshad Ul Haq Bhat * and Rajeev Bhat (ID
}

check for updates

Citation: Bhat, I.U.H.; Bhat, R. Quercetin: A Bioactive Compound Imparting Cardiovascular and Neuroprotective Benefits: Scope for Exploring Fresh Produce, Their Wastes, and By-Products. Biology 2021, 10, 586. https://doi.org/ 10.3390/biology10070586

\section{Academic Editors:}

Almudena García-Ruíz, María del Mar Contreras and Merichel Plaza

Received: 31 May 2021

Accepted: 24 June 2021

Published: 26 June 2021

Publisher's Note: MDPI stays neutra with regard to jurisdictional claims in published maps and institutional affiliations.

Copyright: (c) 2021 by the authors. Licensee MDPI, Basel, Switzerland. This article is an open access article distributed under the terms and conditions of the Creative Commons Attribution (CC BY) license (https:/ / creativecommons.org/licenses/by/ $4.0 /)$.
ERA-Chair for Food (By-) Products Valorisation Technologies (VALORTECH), Estonian University of Life Sciences, 51006 Tartu, Estonia; rajeev.bhat@emu.ee

* Correspondence: irshad.bhat@emu.ee

Simple Summary: The present review summarizes the generated hypothesis and critical role of quercetin in cardiovascular and neuroprotective diseases reported over the last decade. In this review, 335 research articles were referred from the popular scientific database (e.g., Scopus and Web of Science) to elaborate on the importance of quercetin in addressing human ailments and the health-protective role imparted. Being a valuable bioactive compound within the circular economy context, the source for obtaining quercetin has been extended for food industrial wastes/byproducts (mainly of fresh produce). Further, the establishment of the molecular mechanism, antioxidant potential, oxidative stress, metabolic process, myocardial damage, anti neurogenerative potential, enzymatic expression, and ROS inhibition renders quercetin an ideal phytochemical that can provide protective benefits against cardiac and neurodegenerative diseases.

Abstract: Quercetin, a bioactive secondary metabolite, holds incredible importance in terms of bioactivities, which has been proved by in vivo and in vitro studies. The treatment of cardiovascular and neurological diseases by quercetin has been extensively investigated over the past decade. Quercetin is present naturally in appreciable amounts in fresh produce (fruits and vegetables). However, today, corresponding to the growing population and global demand for fresh fruits and vegetables, a paradigm shift and focus is laid towards exploring industrial food wastes and/or byproducts as a new resource to obtain bioactive compounds such as quercetin. Based on the available research reports over the last decade, quercetin has been suggested as a reliable therapeutic candidate for either treating or alleviating health issues, mainly those of cardiovascular and neurological diseases. In the present review, we have summarized some of the critical findings and hypotheses of quercetin from the available databases foreseeing its future use as a potential therapeutic agent to treat cardiovascular and neurological diseases. It is anticipated that this review will be a potential reference material for future research activities to be undertaken on quercetin obtained from fresh produce as well as their respective processing wastes/byproducts that rely on the circular concept.

Keywords: quercetin; secondary metabolite; cardioprotective and neuroprotective agent; fruits and vegetable wastes; by-products; circular economy

\section{Introduction}

Quercetin is a carbohydrate-free flavonoid, a secondary metabolite found in flora, including fresh produce (fruits and vegetables), some of which include red onion, apples, and berries. These compounds have been studied to evaluate the biological activities of flavonoids [1]. The overview depicting the theme of this review is given in Figure 1 [2-4]. These properties of quercetin have been attributed primarily to their antioxidant capacity and free radical scavenging ability. Quercetin intake has been found to affect mitochondrial biogenesis, energy production, electron transport chain performance, ROS production modification, and mitochondrial defect modification $[5,6]$. The antioxidant potential and 
free radical scavenging ability have played a major role in explaining quercetin's neuroprotective effects with the exceptional property of passing the blood-brain barrier. Thus, based on the thorough literature analysis (past decade) from the available databases (in Scopus and Web of Sciences), this review is being designed for cardioprotective and neuroprotective effects. However, to the authors' knowledge, there have been very limited reviews published that have shown cardioprotective and neuroprotective properties for quercetin.

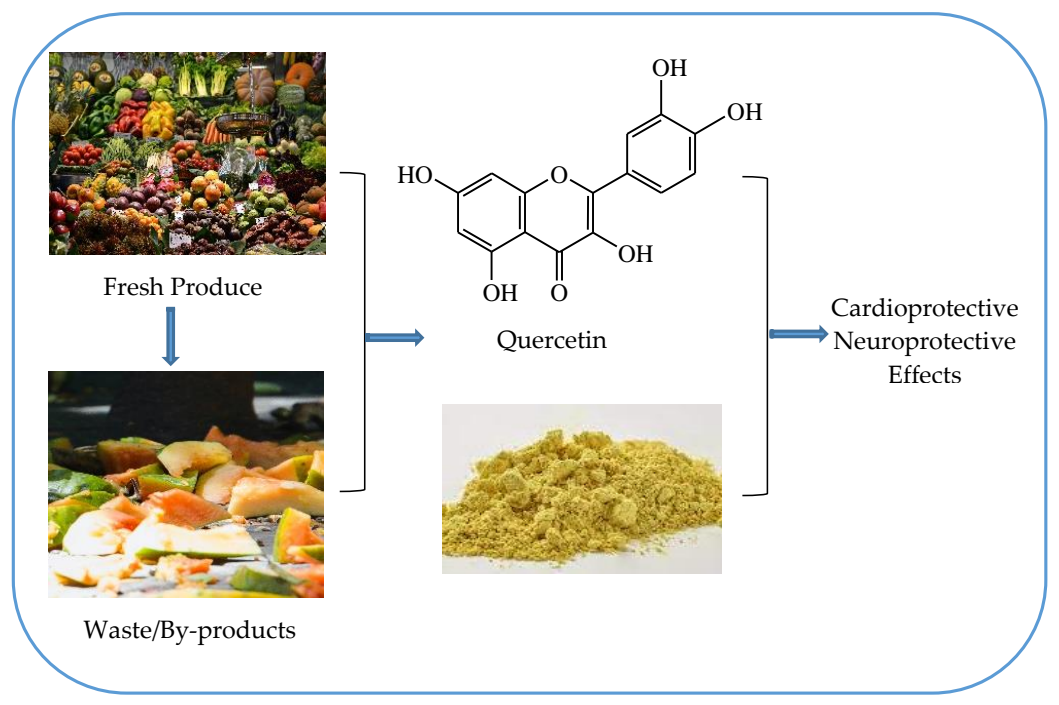

Figure 1. Quercetin: Sources, structure and uses.

On another note, currently, the food industry's post-processing wastes and byproducts have gained much importance in the present-day circular Bioeconomy concept scenario. In the circular economy, an approach contrary to the traditional linear economy (TLE) is adopted; in TLE, products after use are thrown away. These products are manufactured by the extraction and processing of raw materials, usually non-renewable resources. However, the Bioeconomy (BE) includes the production of renewable biological resources and the transformation of these resources and waste streams into added-value products. The meeting point of these three economic concepts as an intersection is the Circular Bioeconomy Concept (CBEC), where the raw material, e.g., biomass, is utilized as renewable resources as it includes byproducts, residues, and waste. This approach retains raw material in a closed material loop and hence enhances productivity. In addition, raw material by the process of recycling can be converted into prototypes of different uses. Fruits and vegetable wastes/byproducts, being a cheap source of raw materials, have been recommended to be exploited for the isolation of bioactive and other value-added compounds. Besides, these wastes and byproducts also help towards minimizing environmental pollution-based issues [7-10]. Hence, there is ample scope to obtain bioactive compounds such as quercetin from fruit and vegetable-based industrial wastes and byproducts. With this background, this review aims to provide guidance and reference for future cardioprotective and neuroprotective aspects of quercetin. Besides, additional focus is also laid towards identifying the potentiality of exploiting food industrial wastes and byproducts to obtain quercetin

\section{Discussion}

\subsection{Quercetin as a Cardioprotective Agent}

Based on pharmacological evidence, quercetin obtained from fruits and vegetables has the tremendous ability to act as a cardioprotective agent. The muscular function is greatly influenced by its antioxidative and antiplatelet properties. These properties prompt actions such as anti-smooth muscle cell proliferation and migration, which in turn improves cardiac cell mitochondrial function and inhibits nuclear factor-kappa light chain-enhancer of activated B cells (NF- $\mathrm{kB}$ ), as stated by Ay et al. [11]. Sengul et al. [3] reported protective 
effects of quercetin in rats and demonstrated that the dosage of $50 \mathrm{mg} / \mathrm{kg}$ and $100 \mathrm{mg} / \mathrm{kg}$ of quercetin have significant protective effects on the 5-FU-induced cardiotoxicity in rats after 14 days of administration. Quercetin can reduce cardiovascular disease linked to brainderived neurotrophic factor (BDNF); in this aspect, Wang et al. [2] stated that quercetin exerted significant antidepressant and cardioprotective effects in mice. A diet of high fat is linked to perturbations in the metabolism of fatty acids and contributes to cardiac diseases such as cardiometabolic syndrome and cardiac damage, which can be alleviated by quercetin by restoring myocardial microcirculation as studied by Yu et al. [12]. The beneficial effects of quercetin help in decreasing plasma triglycerides and intramyocardial fat deposition [12]. Rolnik et al. [13] investigated quercetin derivatives for the development of new anti-platelet strategies and management of current therapies in cardiovascular diseases linked to hyper-activation of platelets. Further, Elbarbry et al. [14] have elaborated the role of quercetin by studying its role in lowering blood pressure. The effect of quercetin in spontaneously hypertensive rats (SHR) was studied by administrating different concentrations of quercetin. The enzymatic activity of rats suggested that medium and high doses of quercetin resisted high blood pressure. They hypothesized that quercetin has anti-hypertensive and provided a novel mechanism for its underlying cardioprotective properties [14]. The protective effects of quercetin against isoproterenol-induced myocardial ischemia and verification of the cellular mechanisms based on the L-type $\mathrm{Ca}^{2+}$ channel (LTCC), $\mathrm{Ca}^{2+}$ transients, and myocardial contractility was reported by Liang et al. [15]. In their animal model, they hypothesized that quercetin gives a cardioprotective effect by inhibiting $\mathrm{Ca}^{2+}$ influx and contractility in experimental animals. Besides, the ' $\mathrm{Zi}$ Shen Huo Luo Formula' (ZSHLF), a traditional Chinese-medicine-(TCM)-based herbal formula, consists of many drug material components. Quercetin is among these components that tend to exhibit cardioprotective effects, as studied by Song et al. [16]. They supported their results by establishing a mechanism by carrying in vitro studies using rats. However, they also insisted that in ZSHLF, major bioactive components or metabolites are responsible for the effects and the implications of these findings in patients and further research is needed. The inhibition of myocardial damage due to recurring chest pain is the main issue in heart disease. The results indicated that the cardioprotective effect of QPC highlights the importance of anti-arrhythmogenic during ischemic heart disease. These results can be a milestone for a new direction for the treatment of myocardial infarction. Quercetin, along with its derivatives, such as rhamnetin, rutin, and hyperoside, has been reported to impart a positive influence on the cardiovascular system [17]. Further, Ferenczyova et al. studied the effects of quercetin and its metabolites on cardiac injury through their antioxidant, anti-inflammatory, and molecular pathways-modulating properties. However, it was revealed that due to a low number of clinical trials focused on cardiac effects of quercetin and its derivatives, clinical data were inconclusive [18]. In their other study, cardiovascular benefits of quercetin in diabetic rats of different ages. It was reported that quercetin might be advantageous for vascular function in diabetes type 2; however, increasing age and/or progression of diabetes may confound its vasculoprotective effects. Though, quercetin was not so effective in preventing myocardial ischemia-reperfusion (I/R) injury in type 2 diabetes and older age [19]. Wang et al. [20], after establishing the structure of quercetin by spectroscopic data, studied its cardioprotective properties. The cardioprotective effects of quercetin against oxidative stress of $\mathrm{H} 9 \mathrm{c} 2$ cells induced by $\mathrm{H}_{2} \mathrm{O}_{2}$ showed quercetin derivatives exhibited protective effects against $\mathrm{H} 9 \mathrm{c} 2$ cells injury induced by $\mathrm{H}_{2} \mathrm{O}_{2}$ The cardioprotective effects of quercetin-containing drugs, corvitin and lipoflavon, were reported first time by Stechyshyn and Pavliuk [21]. Quercetin can relieve endoplasmic reticulum dysfunction in Pak2-CKO hearts. The findings of using quercetin uncovered a new cardioprotective mechanism and therapeutic strategy for encouraging options for treating cardiac disease and heart failure [22]. The cardioprotective index (CI) has been studied in diabetic rats after treatment with quercetin for 28 days. Ogar et al. [23] attributed the enhanced CI to the use of quercetin. The cardioprotective effects of quercetin, along with a dietary supplement, alpha-linolenic acid, have been described by Burak et al. [24].The 
quercetin derivative was used to study cardiac dysfunction, scavenging free radicals, and reduced lipid peroxidation, as reported by Shu et al. [25] and attributed cardioprotective effects of quercetin derivative to partially counteracted PI3K/Akt inhibitor LY294002. Wang et al. [26] isolated glycosidic derivative quercetin and studied their cardioprotective effects against $\mathrm{H}_{2} \mathrm{O}_{2}$-induced apoptosis in $\mathrm{H} 9 \mathrm{c} 2$ cells. At micromolar concentrations, the quercetin glycosides exhibited stronger activity than the acylated quercetin glycosides.

Chakraborty et al. [27] studied quercetin in combination with curcumin as a bio enhancer for ischemia-reperfusion injury (IRI) induced myocardial toxicity in rats. After 30 days of treatment, it was observed that a combination of these two phytoconstituents exhibited intense protection of IRI-induced myocardial toxicity and was further supported by pharmacodynamic interaction [27]. The cardioprotective effects of quercetin in animals exposed to intermittent hypobaric hypoxia (IHH) were studied by Chis et al. [28]. The oxidative/nitrosative stress increases by hypobaric hypoxia in heart tissue and quercetin act as a cardioprotective agent, which reduces the oxidative cardiac dysfunction induced by oxidative/nitrosative stress [28]. Quercetin administration in a group of rats through myocardial energy metabolism restoration gives a prophylactic effect in response to adriamycin-induced toxic effects [29]. LC-MS/MS analysis was performed for the detection and determination of the bioactive constituents, including quercetin, in methanol extract of Alternanthera philoxeroides (Mart.) Griseb. It was revealed by in vitro cell evaluation studies that methanol extracts significantly stopped cardiomyocyte apoptosis [30]. The cardioprotective effects of quercetin against the damage induced by a high-cholesterol (HC) diet in hyperglycemic rats was studied, which was attributed to intracellular antioxidant mechanisms and bioenergetics [31]. These researchers observed that quercetin reduced HC-induced changes in the lipid profile and glycemia in experimental rats. The systolic cardiac function was enhanced in mice administrated with quercetin. The rapid metabolization of quercetin to tamarixetin was maintained at a higher concentration for enhancement of systolic cardiac function, as reported by Hayamizu et al. [32]. Quercetin can exert cardiotonic action via digitalis-like enhancement of $\mathrm{Ca}^{2+}$ transients by itself and its metabolite, tamarixetin.

The effects of quercetin on cardiac parameters and ischaemia-reperfusion (I/R) injury, the Langendroff method was used on male Wistar rats by Garjani et al. [33]. The reported results indicated that at lower quercetin concentrations, a protective effect against I/ $R$ injuries in isolated rat hearts was observed. The conjugation of quercetin with the anticancer drug doxorubicin was evaluated by Alrushaid et al. [34] to understand its cardioprotective effects and the mechanism involved. The cardioprotective mechanism of conjugated doxorubicin-quercetin involved scavenging of ROS and CYP1B1 inhibition. The cardioprotective roles of quercetin against I/R injury and the underlying mechanism based on molecular signaling were reported by Li et al. [35]. The model based on oxygen-glucose deprivation/reoxygenation (OGD/R) of I/R was reported in myocardial H9c2 cells in the absence or presence of quercetin. Their results supported the fact that a dual character of quercetin is involved in the process of myocardial I/R. The extensive data reported by Ballmann et al. [36] revealed that quercetin improves various metabolic processes such as mitochondrial biogenesis and antioxidant enzymatic action. The availability of quercetin facilitates dystrophin-associated glycoprotein complex (DGC) assembly and decreases inflammation in dystrophic hearts. Along with other polyphenols, quercetin was studied for cardioprotective potential in different fractions of Syzygium cumini L. seeds [37]. The control of angiotensin-converting enzyme (ACE), HMG-CoA reductase, LDL oxidation, and tertiary butyl hydrogen peroxide (TBHP) was exhibited by Syzygium cumini L. seed fractions rich in quercetin content. The investigation on streptozotocin-nicotinamide-induced adult male diabetic rats administrated quercetin with different concentrations orally for 28 days. A decrease in glucose levels in addition to the reduction in other necessary parameters, including cardiac injury marker levels, were found. They hypothesized that quercetin could be used to improve myocardial damage due to oxidative stress, inflammation, and apoptosis in diabetes [38]. In preventive therapy for cardiac disease, cardioprotection 
represents one of the most important and realistic aspects, and quercetin helps to a great extent in providing cardioprotection. Kumar et al. [39] explored the cardioprotective activity of quercetin and related mechanisms. Wister rats were given quercetin orally for 14 days. It was observed that quercetin pre-treatment exhibited protective effects on the heart. Isoproterenol-induced oxidative stress, inflammation, protection of heart architecture, and down-regulation of the expression of calpain were significantly reduced by quercetin treatment. Thereby concluded that quercetin has cardio-protective potential and established its mechanism of action against isoproterenol-induced myocardial infarction (MI) in experimental rats. The inhibition of chronic-unpredictable-stress-(CUS)-induced left ventricular dysfunction (LVD) in rats by quercetin in an animal model was studied by Bin-Jaliah [40]. It was hypothesized that quercetin tends to prevent myocardial infarction (MI) induction by CUS. The rats were treated with a constant dosage of quercetin for 3 weeks. The measurable parameters, such as blood pressure and electrocardiogram (ECG), along with histological study, were taken into consideration prior to quercetin treatment. It was observed that quercetin treatment lowered blood pressure and substantially prevented MI attributed to the blocked elevation of the ST-segment on the ECG. Furthermore, the significant inhibition of expression of Bax RNA messages and blocked CUS-induced TNF- $\alpha$ and IL- 6 upregulation led to the efficacy of quercetin treatment. Thus, a possible therapeutic role for quercetin in CUS-induced cardiac dysfunction was established by Bin-Jaliah [40]. Quercetin was studied for its effect on myocardial ischemia in patients with stable coronary heart disease (CHD) by Chekalina et al. [41]. With the intake of constant dosage of quercetin for 45 days, the deceleration time (DT) value and premature ventricular contraction (PVC) number dropped significantly by the usage of quercetin. Thus, the cardioprotective properties of quercetin in conditions of CHD were recognized. The generation and excessive production of reactive oxygen species (ROS) lead to oxidative stress in the body and are considered major reasons for cardiovascular diseases (CVDs). The production of reactive radicals is one of the major management strategies for CVDs along with other factors and can be controlled by quercetin, as reported by Ramachandran et al. [42]. Quercetin treatment for isoproterenol-induced toxicity in H9c2 cardiomyoblast cells was studied. The treatment with quercetin prompted a protective effect by augmenting the antioxidant prominence of the cells [42]. Thus, based on animal models, oxidative stress, metabolic process, myocardial damage, enzymatic expression, ROS inhibition, and cell line studies, an extensive approach has been opted to establish the importance of quercetin as a cardioprotective agent. Some of the selected works reported on the role of quercetin as a cardioprotective agent are given in Table 1. 
Table 1. Some recent reports on the role of quercetin as a cardioprotective agent.

\begin{tabular}{ccc}
\hline Role & Mode & Reference \\
\hline $\begin{array}{c}\text { Translocation of NFkB, and expression of TGF- } \beta \text {, CTGF, } \\
\text { and BNP }\end{array}$ & In vivo & [43] \\
\hline $\begin{array}{c}\text { Cardioprotective effects restoring plasma thyroid } \\
\text { hormone levels and attenuating oxidative stress in } \\
\text { the heart }\end{array}$ & In vivo & [45] \\
\hline $\begin{array}{c}\text { Inhibition of JNK and p38 mitogen-activated protein } \\
\text { kinase signaling pathways }\end{array}$ & In vivo & [46] \\
\hline $\begin{array}{c}\text { Inhibits angiotensin-converting enzyme activity, improves } \\
\text { vascular relaxation, and decreases oxidative stress and } \\
\text { gene expression }\end{array}$ & In vitro, in vivo \\
\hline $\begin{array}{c}\text { Post-ischemic recovery of left ventricular developed } \\
\text { pressure, as well as recovery of markers of contraction } \\
\text { and relaxation, respectively }\end{array}$ & In vivo \\
\hline Cardioprotective & In vivo & [48] \\
\hline $\begin{array}{c}\text { Myocardial infarction } \\
\text { Release of creatine kinase-MB (CK-MB), lactate } \\
\text { dehydrogenase (LDH) level in coronary effluent and } \\
\text { reduced myocardial infarct size }\end{array}$ & In vivo \\
\hline
\end{tabular}


Table 1. Cont.

\begin{tabular}{|c|c|c|}
\hline Role & Mode & Reference \\
\hline $\begin{array}{l}\text { Myocardial ischemia-reperfusion injury via suppressing } \\
\text { the NF-kB pathway }\end{array}$ & In vivo and in vitro & {$[50]$} \\
\hline $\begin{array}{c}\text { Protein disulfide isomerase (PDI) inhibition for } \\
\text { cardiovascular benefits }\end{array}$ & In vitro & [51] \\
\hline $\begin{array}{l}\text { Protects cardiomyocytes against oxidative toxicity and the } \\
\text { regulation of stress-sensitive protein kinase cascades and } \\
\text { transcription factors. }\end{array}$ & In vitro & [52] \\
\hline Lowers $\mathrm{ABP}$ in patients with hypertension & In vivo & [53] \\
\hline Cardioprotective control & In vitro & {$[54]$} \\
\hline $\begin{array}{l}\text { Endothelial function and reducing inflammation, vascular } \\
\text { function, and cardiometabolic health }\end{array}$ & In vivo & {$[55,56]$} \\
\hline $\begin{array}{l}\text { Improve cyclosporine-induced cardiotoxicity, as it has } \\
\text { antioxidant and anti-inflammatory enzyme activities }\end{array}$ & In vivo & [57] \\
\hline Atherogenic and cardioprotective indices & In vivo & [58] \\
\hline Reduction in cardiac and renal markers of oxidative stress & In vivo & [59] \\
\hline $\begin{array}{l}\text { Antichronic doxorubicin cardiotoxicity via antioxidant } \\
\text { and anti-inflammatory properties }\end{array}$ & In vivo & [60] \\
\hline Antioxidative cardiotoxicity and dyslipidemia & In vivo & [61] \\
\hline $\begin{array}{c}\text { Cardiac weight index and myocardial enzyme activity } \\
\text { Antioxidative stress, inhibition of the } \\
\text { renin-angiotensin-aldosterone system }\end{array}$ & In vivo & [62] \\
\hline Ischemia/reperfusion injury in cardiomyocytes & In vitro & [63] \\
\hline $\begin{array}{l}\text { Anti-doxorubicin-induced cardiomyopathy in } \mathrm{H} 9 \mathrm{c} 2 \text { cell; } \\
\text { myocardial ischemia/reperfusion injury in rats through } \\
\text { the PI3K/Akt pathway }\end{array}$ & In vitro & {$[64,65]$} \\
\hline $\begin{array}{l}\text { Induce activation of AMPK and eNOS in human aortic } \\
\text { endothelial cells }\end{array}$ & In vivo & [66] \\
\hline Cardioprotective effect of GSK-3b inhibitors & In vivo & [67] \\
\hline $\begin{array}{l}\text { Reduction of the serum CK-MB, LDH, and SGPT } \\
\text { level enzymes }\end{array}$ & In vivo & {$[68]$} \\
\hline $\begin{array}{l}\text { Protects rat hearts from oxidative stress by its } \\
\text { antioxidant potential }\end{array}$ & In vivo & [69] \\
\hline $\begin{array}{l}\text { Decrease in doxorubicin-induced cytotoxicity and } \\
\text { promoting the cell repair system in cardiomyocyte } \\
\text { H9C2 cells }\end{array}$ & In vitro & [70] \\
\hline
\end{tabular}

\subsection{Quercetin as a Neuroprotective Agent}

A unique four-step strategy comprising of 'Global profiling', 'Chemical structural classification', 'Intra-group screening', and 'Component-knockout optimization' was adopted to screen and optimize the functional compound combination (FCC) from traditional Chinese medicine (TCM). The holistic neuroprotective effects of the FCC consisting of quercetin indicated antioxidative and anti-inflammatory responses in PC12 cells to save them from oxidative stress, as reported by Wang et al. [71]. The group hypothesized that the reported strategy could offer an alternative to discover phytochemicals of biological importance, such as quercetin used in traditional medicines. The hexane extract of Spondias mombin L. (Anacardiaceae) 'Cajazeira' containing quercetin has shown a neuroprotective effect via anxiolytic and antioxidant activities in zebrafish [72]. The study on elaboration mechanism explaining the effects of extract containing quercetin on neuroprotective benefits was established. Eclipta alba L. 'Bhringra' hydroalcoholic extract containing quercetin 
along with other phytoconstituents was reported by Bhatia et al. [73]. It was further stated that cellular antioxidant and enzymatic expression showed improvement by using Eclipta alba L. extract, therefore projecting this as a potential plant for the generation of the therapeutically neuroprotective agent. The first-time isolation and identification of quercetin glycosidic derivative from Hibiscus rosasinensis L. was reported by Shen et al. [74]. This derivative was suggested for the prevention of Alzheimer's disease. The effect of quercetin-loaded microcapsules was analyzed for neuroprotective properties in Wistar adult rats by studying nitrergic neurons reducing oxidative damage [75]. In a comparative study by Jalili-Baleh et al. [76], quercetin was chosen as the standard for a neuroprotective activity for chromone-lipoic acid hybrids. The use of quercetin can protect retinal cells from deterioration and had not dilapidated their function [77]. The researchers related the protective effect of quercetin and other phytoconstituents to higher expression of certain proteins (photoreceptor-specific proteins), photoreceptors (rhodopsin and cone opsins), and at the same time to reduced expression of particular inflammatory markers.

The dietary intake of quercetin was recently studied in an animal model (mice) by Zhang et al. [78] to establish its role in reducing depression, a true neurological problem. These findings supported astrocyte reactivation in the regulation of quercetin neuroprotection and hypothesized that a quercetin-rich diet intake in fruits, vegetables, and food additives would relieve the stress. The effect of injected quercetin at different intervals in neonatal mice with hypoxic-ischemic brain injury was reported by Le et al. [79] to study its neurological functions. The administrated quercetin protected microglial cells (BV2 cells) from oxygen-glucose deprivation (OGD) induced damage; further microglial oxidative stress-related molecules were intercepted. The hepato-neuroprotective effect of extracts of Barnebydendron riedelii Tul. was attributed to its quercetin content by Baraka et al. [80]. It was stated that glycosidic quercetin, through its modulatory effects on NF$\mathrm{\kappa B} / \mathrm{IL}-6$ and Nrf2/HO-1 signaling pathways, is enabled to exhibit a protective effect. A quercetin-integrated Cyclodextrin complex was studied for its neuroprotective behavior in nose-to-brain Que's delivery systems [81]. The obtained results were warned further ex vivo and in vivo studies for delivery of specific targeted delivery. Quercetin and quercetin $4^{\prime}$-O-glucoside were biologically evaluated for cerebral ischemia-reperfusion in mice. The quercetin extractives from different extracts showed different neuroprotective effects. It was suggested that further evaluation for neurotoxic effects and appropriate neuroprotective mechanisms should be continued to explore [82]. The neurotoxic damage induced by Bisphenol-A (BPA) in zebrafish (Danio rerio) and the effect of quercetin supplement treatment was carried out by Sahoo et al. [83]. The neurobehavioral response, oxidative stress, and neuromorphological changes were observed by the use of quercetin and it was considered as an effective agent to intervene in the induced neurotoxicity in Zebrafish by BPA. The delivery of drugs while crossing the blood-brain barrier (BBB) to a selected site to treat Parkinson's disease (PD) is a challenging issue. Thus, modification in treatment is needed; in this aspect, nanoparticles were used to carry the drugs to the selected target. Quercetin is an anti-Parkinson disease agent, and recently Liu et al. [84] used gold nanoparticles loaded with quercetin to study the enhancement in BBB permeability of quercetin via the photothermal effect. The results revealed that by this treatment, quercetin was accumulated in the brain and it was further hypothesized that nanoparticles could have the potential for neuroprotective drug delivery and treatment for PD. In another study, quercetin nanoparticles were studied for their better availability. A constant dose of quercetin nanoparticles was administrated to animals along with $\mathrm{AlCl}_{3}$. Based on microscopic results, nanoparticles showed neurogenerative changes and improvement of tyrosine hydroxylase (TH), and this study was the first study revealing the therapeutic effects of quercetin nanoparticles for Alzheimer's disease (AD) model and further investigation was warned by Rifaai et al. [85]. Neuroprotection against cerebral ischemia/reperfusion injury in rats was studied by Wang et al. [86] using quercetin oral pretreatment. Neuroprotective parameters such as brain infarction, blood-brain barrier disruption, oxidative stress, TNF- $\alpha$, and IL- $1 \beta$ mRNA expression, along with apoptotic caspase 3 activity, and with 
neuroprotective, anti-oxidative, anti-inflammatory, and anti-apoptotic effects of quercetin, were reported. The increase in ERK/Akt phosphorylation and protein phosphatase activities and at the same time inhibition of ERK or Akt were studied to report the cause of apoptotic cell death and cytotoxicity in hippocampal slice cultures and neuron/glia cultures. In conclusion, it was hypothesized that the role of quercetin was prominent in improving the protein tyrosine and serine/threonine phosphatase activity, followed by reduction of ERK and Akt phosphorylation, thereby addressing the important role of quercetin in understanding its neuroprotective behavior [86]. The administration of quercetin supplementation leads to an increase in the bioavailability of NO in the jejunum in euglycemic diabetic rats. This treatment reduces the effects of diabetes on nNOS-IR neurons and VIP-IR varicosities in the myenteric plexus of experimental diabetic rats, as reported by Martins-Perles et al. [87]. The presence of quercetin in Camellia nitidissima Chi, 'Tea for Longevity' a well-known plant consumed as both medicine and food in China, was studied for its neuroprotective effect by An et al. [88]. Based on two used terms, 'synergistically boosting endogenous antioxidant defences' and 'neurotrophic signalling pathway' by An et al. [88], this plant has been cited as an important source for phytonutrients, including quercetin for edible foods and beverages. Soxhlet extraction to yield quercetin along with other phytoconstituents from Pinus roxburghii Sarg. by Sharma et al. [89] for in vivo and in vitro studies was carried out to evaluate neuroprotective activity in rats. It was reported by Karaman et al. for the first time that quercetin obtained from mushrooms (Coprinus comatus (O.F.Mull.) Pers.) exhibited neuroprotective activity [90]. This plant has been cultivated in China and can be used as an acetylcholinesterase (AChE) inhibitory agent. The work on dopaminergic human SH-SY5Y cell lines using quercetin was evaluated for the neuroprotective role [91]. The impact of rotenone-induced neurotoxicity in SH-SY5Y cell lines was studied by correlating intracellular reactive oxygen species (ROS) and imbalance in the mitochondrial membrane potential (MMP). It was established that quercetin gave cells protection against rotenone; this quercetin was hypothesized as a therapeutic agent with significant neuroprotective potential. The neuroprotective effect and control of gut microbiota linked with nerve damage in diabetic rats using quercetin were studied by Xie et al. [92]. It was suggested that quercetin has a therapeutical potential to reduce diabetic peripheral neuropathy (DPN) in rats and can be considered as a key component for the treatment of such neuropathic-related issues. The role of quercetin in treating neurotoxicity caused by metronidazole by obstructing the proportion of antioxidants in the brain tissue and inducing nitric oxide synthesis along with apoptosis. Quercetin was found active to protect against such neural damage by Chaturvedi et al. [93]. Nanoparticles can enhance the delivery of quercetin, as stated by Pinheiro et al. [94]. The blood-brain barrier was targeted by such designed nanoparticles. By this approach, the neuron was protected against amyloid-beta fibrillation; thus a targeted delivery of quercetin was achieved, and a novel strategy to treat Alzheimer's disease can be generated. The hydroalcoholic extract of coffee silverskin containing quercetin along with other polyflavonoids was reported for its neurodegenerative activity attributed to counteract oxidative stress and maintain cell viability [95]. The neuroprotective activities in rats using quercetin were determined by de Mattos et al. [96]. The neuroprotective properties of quercetin for treating autism in an animal model is being hypothesized as an important therapeutic candidate for addressing neurological disorders such as autism spectrum disorders (ASDs). Quercetin with hydroxyl groups on the ortho position can have been reported to provide enhanced neuroprotection as reported by Lossi et al. [97]. This study contributed towards a new finding in the translation application of polyphenols, as stated by the researchers. The spectroscopic analysis was used to characterize lipid nanoparticles encapsulated with quercetin and used as neuroprotective agents. The results revealed that the nanoparticles are appropriate for brain applications, particularly for Alzheimer's disease, due to the inhibition of amyloid-beta aggregation [98]. Quercetin was found as a major constituent in the methanolic stem extract of Colebrookea oppositifolia Smith. with a potential of cerebroprotective activity against ischemia-reperfusion-induced brain injury during in vivo studies [99]. 
The oral administration of quercetin at constant dosage in mice was studied for the counter effects of Aflatoxin B1, a mycotoxin in mice. The antioxidant effect of quercetin led to a preventive role against oxidative stress by supporting antioxidative defense systems and restraining the lipid peroxidation process [100]. Euonymus alatus (Thunb.) Siebold. a food plant consumed as traditional medicine in East Asian countries, has been found rich in quercetin. The extract from the plant was utilized for anti-neurotrophic factors. The defense in the mouse hippocampus from scopolamine-induced damage through as brain-derived neurotrophic factor-mediated Nrf2 activation was established by the use of quercetin by diminishing cognitive decline [101]. The potential toxin in diet responsible for the pathogenesis of Alzheimer's disease (AD) is dietary advanced glycation end products (dAGEs), as stated by Yang et al. [102]. Thus, experimental mice were treated with quercetin after giving dAGEs for 21 days. The results evaluating different biochemical pathways suggested that treatment by quercetin supplication has improved cognitive function in experimental animals. A similar study was carried out by Yang et al. [103] by stating that extended application of quercetin may be beneficial for high consumers of dAGEs. The neurotoxicity by the exposure of pesticide fenitrothion has led Ibrahim et al. [104], to carry out a study in rats for the role of quercetin against the development of such neurological impairment. The study leads to the hypothesis that quercetin can prove helpful against fenitrothion by downregulating apoptosis-related genes and catecholamines. Thus, it can be exploited as a neuroprotective agent. Shalavadi et al. [105] carried out the neuroprotective capability of Convolvulus pluricaulis Choisy extracts and their comparison with quercetin in mice. Diabetic encephalopathy (DE) can be improved by the use of quercetin as established by studying the SIRT1/NLRP3 pathway by Vieira-Frez et al. [106]. The crucial link between the use of quercetin and neuroprotective efficacy in diabetic encephalopathy (DE) was reported by them in mice. A similar study was reported by Hu et al. [107] wherein SIRT1/NLRP3 pathway was considered a crucial mechanism for the neuroprotective effect against DE using quercetin in mice used as a diabetic model animal [107]. The results presented by Park et al. [108] were able to justify that quercetin can be considered as an active component for mediating the neuroprotective role by controlling thioredoxin expression and maintaining the interaction between apoptosis signal-regulating kinase 1 (ASK1) and thioredoxin, an antioxidant. The findings suggest that quercetin mediates its neuroprotective function by regulation of thioredoxin expression and maintenance of interaction between ASK1 and thioredoxin. Quercetin in combination with piperine was studied for neuroprotective effect against rotenone- and iron-supplement-induced PD in experimental rats. It was found that this combination was quite effective in treating Parkinson's disease (PD) in rats [109]. The neuroprotective effects of quercetin in Wistar rats as subarachnoid hemorrhage (SAH) model animals for its role in visualizing the effects against cerebral vasospasm was reported by Gül et al. [110]. The biochemical and histopathological evaluation reported revealed that quercetin has a crucial role in SAH therapy by stopping vasospasm. The copper-induced neurodegeneracy in injured P19 neuronal cells can be countered by the use of quercetin, as stated by Zubčić et al. [111]. MTT assay, preventing ROS formation, caspase-3 activation, and chromatin condensation by using $150 \mu \mathrm{M}$ quercetin was the basis to prove the neuroprotection offered by it. However, further detailed pharmacological and toxicological studies to establish its role were warned. The controlled and sustained release of quercetin at targeted neuron cells was carried out by loading quercetin poly (D,L-lactide-co-glycolide)-poly(ethylene-glycol)-poly(D,L-lactideco-glycolide) (PLGAPEG-PLGA) hydrogel. The results obtained suggested that oxidative damage and inflammation in the spinal cord were improved along with increase neuron survival rate and promotion in nerve regeneration and motor function recovery. The authors suggest that the sustainable approach of quercetin delivery has promising applications in the clinical treatment of brachial plexus avulsion (BPA) [112]. Based on the study carried out by Yu et al. [113] the increase in the survival rate of PC12 injured by A $\beta 25-35$, promotion of cell proliferation, and antagonization of the toxicity of $\mathrm{A} \beta$ due to quercetin, led it to be considered as a strong agent as a drug candidate for the treatment of Alzheimer 
disease. The neurotoxic effects of styrene 7,8-oxide (SO) and its cytotoxicity mechanism were studied using quercetin as a neuroprotective agent. The presented results were in agreement that cytotoxicity of $\mathrm{SO}$ was mediated by oxidative stress and apoptosis, necrosis, and necroptosis mechanisms, and at the same time, quercetin delivered the neuroprotection [114]. Quercetin 3, 7-O- $\alpha$-L-dirhamnoside, a quercetin derivative, was found actively in providing a protective effect against induced neurotoxicity [115]. The brain targeting of quercetin-loaded exosomes enhanced its bioavailability in Alzheimer's disease (AD) and further relieved the symptoms of AD via inhibition of biochemical pathways such as cyclin-dependent kinase 5 (CDK5)-mediated phosphorylation of phosphoprotein Tau and decrease of the formation of insoluble neurofibrillary tangles (NFTs) [116]. Malik et al. [117] and Gao et al. [118] exploited extracts Lactuca sativa L. and Lycium ruthenicum Murr. extracts rich in quercetin content, and proved their neuroprotective potential. Chronic neuroinflammation is the leading cause of anxiety issues. Quercetin has been proven to reduce such inflammation and can be considered as a potential agent for inhibiting anxiety-like symptoms in neuropsychiatric diseases, as stated by Lee et al. [119]. Nanoquercetin via endocytic cell proliferation can be slowly released as seen in the model studies and has shown better action as compared to quercetin, thus can be considered as a new milestone for providing treatment for Alzheimer's disease [120]. The Enteric Nervous System (ENS) is affected by arthritis, and Piovezana Bossolani et al. [121] studied the impact of quercetin alone and in combination with ibuprofen for 60 days in rats and found that combination treatment was found to be remarkably effective in treating arthritis, thus ENS [121]. Quercetin derivative was also found to be effective in diabetic rats to control neurological damage [122]. Quercetin exhibited neuroprotective effects on cell viability, morphology, and gene expression following corticosterone exposure, as reported by Donoso et al. [123]. It was hypothesized that quercetin defends cortical cells against corticosterone-induced cytotoxicity and, at the same time, improves cell survival through the Nrf2 pathway and expression of Fkbp5. Similarly, Nrf2 dependent HO-1 signaling by quercetin derivative was found a potential agent in addressing Parkinson's disease management [124]. Quercetin was found to bind regulatory sites in $\alpha 7-\mathrm{PAM}$, leading to a reduction in reactive oxygen species. This allosteric property of quercetin, as reported by Nielsen et al. [125] was considered as scaffolds for the development of new neuroprotective therapeutic candidates. The calorimetric MTT assay was carried out to investigate the effect of quercetin as compared with estrogen in its role in Alzheimer's diseases and was able to establish its role in neuroprotection [126]. The blueberry extracts rich in quercetin were administrated in mice at different concentrations. The neuroprotective and antidepressant-like effects were attributed to the presence of a high concentration of flavonols and pigments such as quercetin and anthocyanin, respectively [127]. Similarly, Viola cornuta L. and Viola $\mathrm{x}$ wittrockiana Gams edible flower extracts were examined for neuroprotective effect against paralysis in round worm (Caenorhabditis elegans) by Moliner et al. [128]. They claimed that quercetin derivative quercetin-3-O-(6-O-rhamnosylglucoside)-7-O-rhamnoside was responsible for the neuroprotective properties. Pistacia lentiscus L. leaves extract (PL) containing quercetin and quercetin rhamnoside also exhibited neuroprotective potential investigated in a mice animal model, as mentioned by Azib et al. [129]. The synergetic effect of quercetin in combination with sitagliptin has shown neuroprotective potential in $\beta$-amyloid (A $\beta$ )-induced Alzheimer's disease in male Sprague Dawley rats as reported by Li et al. [130]. Wu et al. [131] treated brain-injured rats with quercetin and hypothesized that quercetin could be used as a therapeutic drug to alleviate the injury caused in the brain by hypoxic ischemia. Quercetin, in its neuroprotective role, was considered to prove a beneficial moiety in controlling the oxidative-induced apoptotic events during insecticide chlorpyrifos exposure in rats [132]. It was witnessed that for chlorpyrifos treated rats, a substantial drop in the protein expression level of $\mathrm{Bcl}-2$ occurred, but at the same time, a notable increase in the expression levels of Bax, cytochrome c, caspase-8, and caspase-9 was observed in the cerebrum and cerebellum, thus justifying the role of quercetin as a neuroprotective agent. 
Among the isolated flavonoids from the medicinal herb Achyrocline satureioides Lam D.C. (Compositae) 'marcela' quercetin was found more effective as compared to luteolin and isoquercitrin in providing neuroprotection [133]. In hypoxia-induced injury of pheochromocytoma (PC-12) cells, quercetin was found to be effective by activating AMPK and Wnt/ $\beta$ - catenin signaling pathways via down-regulation of miR-122 as reported by Yan et al. [134]. Quercetin was reported to be found in the brain and other organs, including tumors induced in mice for studying the intake of Ilex paraguariensis A. St.-Hil [135]. They hypothesized that quercetin and chlorogenic acid present in Ilex paraguariensis A. St.-Hil, if taken in diet, can reduce lung cancer-related neuroinflammation. Chlorpyrifos, a pesticide, has been found to alter neuro-histoarchitecture. After treatment with quercetin, a significant improvement was observed. It was suggested that quercetin prevents chlorpyrifos-induced neurotoxicity [136]. The quercetin derivatives obtained from apple tree leaves showed a significant neuroprotective effect at low concentrations of $0.5-1.0 \mathrm{mg} / \mathrm{L}$ as compared to other phytoconstituents [137]. The results presented by Chatterjee et al. [138] revealed the neuroprotective importance of quercetin in treating dorsal root ganglion (DRG) neurons exposed to radiation-induced ER stress. The neuroprotective role of quercetin against oxidative stress-related neurodegenerative ailments in cortical brain tissue cultures from Wister rats was studied [139]. Further, the effective role of quercetin in neuron survival, Polyphenol-enriched micronutrient mixture, PMM containing quercetin was also studied for the neuroprotective potential [140]. The neuro potential of PMM was justified by explaining the inhibitory activity on $\mathrm{CBP} / \mathrm{p} 300$ or stimulating activity on the AMP-activated protein kinase-sirtuin 1 pathway. Achyranthes aspera L. aerial parts were subjected to alcoholic extraction to examine their cerebroprotective potential [141]. The detailed study presented explained the suppression of ROS generation nitrite and TNF- $\alpha$ in LPS activated RAW 264.7 cell lines. Quercetin treatment reduced the increase of neurological deficit and infarction, as reported by Park et al. [142] by explaining the respective biochemical pathways and expressions. Quercetin has shown anti-hypoxic-ischemic injury (HI) in neonatal mice following the IKK- $\beta / \mathrm{NF}-\mathrm{kB}$ pathway, as reported by Jing et al. [143]. Thus, supporting quercetin as a significant neuroprotective role in preventing brain injury. In an experimental study, administration of quercetin with different doses in 30 male Wistar rats was carried out wherein it was suggested that quercetin could be an alternative for the treatment of spinal cord injury [144]. Kumar et al. [145] reported improved neuronal survival after exposure to $\mathrm{HgCl}_{2}$ using quercetin and caffeine in hippocampal neurons. The term 'disease-modifying drugs' was referred to as these phytochemicals as these can serve as future drugs for neurological disorders (e.g., Alzheimer's disease). The alcoholic and hexane extract of pumpkin flowers (Cucurbita maxima Duchesne ex Poir) were investigated for neuroprotective potential. The chromatographic results revealed that quercetin was found in high concentrations. The cholinesterases (acetylcholinesterase and butyrylcholinesterase), monoamine oxidase (MAO), and $\mathrm{Na}^{+} / \mathrm{K}^{+}$ATPase activities were carried out to establish the neuroprotective activity of extracts [146].

Various phytochemicals, including quercetin derivative, were isolated from natural tea Armeniaca sibirica L., and their neuroprotection role was studied by Zhang et al. [147]. They hypothesized that Armeniaca sibirica L. has promising potential use in the food industry and addresses neuroprotective issues. Diabetes is associated with brain damage in mice as stated by Zhu et al. [148] the use of quercetin at high doses increased the levels of reduced glutathione and activity of superoxide dismutase and thus decreased the levels of advanced glycation end-products. The improvement in diabetic encephalopathy using quercetin was established by citing the decrease in protein glycation, oxidative stress, and inflammation through the upregulation of Glo-1 [148]. Quercetin at the dosage of $50 \mathrm{mg} / \mathrm{kg}$ body weight was reported to help to decrease the symptoms of Alzheimer's disease [149]. The microscopic analysis revealed that quercetin suppressed $\mathrm{H}_{2} \mathrm{O}_{2}$ - induced changes in cell membrane elasticity and morphological properties, leading to the hypothesis of the neuroprotective role of quercetin [150]. The iron nanoparticles loaded with quercetin were evaluated for crossing the brain barrier in Wistar rats. After an oral dosage of $100 \mathrm{mg} / \mathrm{kg}$ 
body weight of quercetin, the plasma and brain tissue were found to contain a higher amount of iron nanoparticles as compared to neat quercetin. This availability has suggested that these loaded nanoparticles can be used as neuroprotective agents [151]. The alcoholic extract of Colebrookea oppositifolia Smith. was found to be rich in quercetin as detected via LC-MS results by Viswanatha et al. [152]. The in vivo experiment was carried out in Wistar rats and found to exhibit a cerebroprotective effect. The inhibition of ROS, nitrite, and TNF- $\alpha$ in LPS-stimulated RAW 264.7 cell lines has supported its neuroprotective effect. The reduction of size in quercetin to the nanometric range will increase its bioavailability at the targeted site, as stated by Ghaffari et al. [153]. The 6-hydroxydopamine (6-OHDA) induced Parkinson-like model in male rats was studied by them, who reported that treatment with nanoquercetin prevented the disruption of memory while increasing antioxidant enzymatic activities such as SOD and catalase decreased the Malondialdehyde (MDA) level in the hippocampal area of the brain, thus supporting their provided hypothesis of using quercetin as an anti-Parkinson agent in rats [153]. Similarly, the combination of quercetin with bio-enhancer piperine has been reported [154] to counter 6-OHDA-induced Parkinson's diseases in rats. The quercetin was effective against radiation-induced brain injury in Wistar rats [155]. The antioxidant and histopathological results revealed that quercetin is favorable as a neuroprotective agent. The quercetin was found active against levodopa-induced toxicity in neuroblastoma (SH-SY5Y) cells of olive biophenols, and based on its enzymatic reaction, it has been hypothesized as a promising natural inhibitor against the histone deacetylases (HDAC) enzyme by Omar et al. [156]. The traumatic brain injury (TBI) in rats were treated with quercetin using Neurological Severity Scoring, immune histochemical, and Western blot analyses. The use of quercetin exhibited significant inhibition in extracellular signal-regulated kinase $1 / 2$ phosphorylation and activated Akt serine/threonine-protein kinase phosphorylation, thus proving its neuroprotective potential [157]. The pesticide-induced oxidative stress in the brain of rats was treated with quercetin. The reduction in oxidative stress and increases expression of paraoxanase 2 enzyme (PON2) in cultured neural cells led to neuroprotection against oxidative exposure. Thereby, it proved its role as a neuroprotective agent [158]. Quercetin and biapigenin into poly ( $\varepsilon$-caprolactone) (PCL) nanoparticles were studied for their neuroprotective behavior by Oliveira et al. [159]. The focal cerebral ischemia was induced in male Sprague Dawley rats, and after treatment with quercetin neurological function test, brain edema measurement, and 2,3,5-triphenyl tetrazolium chloride staining were carried out to establish its effectiveness as a neuroprotective agent. It was hypothesized that quercetin was successful in preventing the middle cerebral artery occlusion induced activation of apoptotic pathways affecting caspase- 3 and poly ADP-ribose polymerase expression, thereby establishes its neuroprotective candidature [160]. Quercetin has been found extremely beneficial for nerve regeneration in the Sprague Dawley rat model of sciatic nerve crush injury using histopathological, morphometric, and biochemical methods as reported by Türedi et al. [161]. Domoic acid (DA), a well-known neurotoxic agent, damages the hippocampal area in the brain. Wang et al. [162] studied the effect of quercetin on DA-induced neurotoxicity in mice. To their findings, a reduction in mitochondrial dysfunction via increase of AMPK activity, coupled with an increase in Nrf2 pathway mediated oxidative defense has been cited as a probable reason to hypothesize quercetin as a neuroprotective agent. Traumatic brain injury (TBI) and the potential role of the PGC- $1 \alpha$ pathway neuroprotection using quercetin were studied in Wild-type mice by Li et al. [163]. Quercetin treatment can reduce brain injury in TBI model mice by increasing the activities of mitochondrial biogenesis through the mediation of the PGC- $1 \alpha$ pathway. The neuroprotective behavior of quercetin in rats can be attributed to the inducing effects on the expression levels of the brain-derived neurotrophic factor mRNA [164].

The membrane permeability is a concerning issue while delivering quercetin at the injured brain site during 'Cerebral ischemia-reperfusion', which results due to the generation of reactive oxygen species. Thus, quercetin was loaded on polymeric nanocapsules and directed towards mitochondria and was able to higher brain uptake, thereby controlling 
both generations of ROS as well as the specific delivery of quercetin in the brain [165]. The effect of quercetin on hippocampal neurons after $\mathrm{H}_{2} \mathrm{O}_{2}$ and $\mathrm{A} \beta$-induced neurotoxicity was treated with quercetin. It was hypothesized by Godoy et al. [166] that quercetin can be considered as extraordinary means for justifying and explaining molecular mechanisms associated with $\mathrm{A} \beta$ neurotoxicity. The extract from Bougainvillea glabra Choisy leaves extract rich in quercetin was considered effective in preventing neurological disorders. The study was supported based on the results of improved locomotor performance and decreased AChE activity, ROS production, and lipid peroxidation [167]. Similarly, extracts from Bacopa monnieri were found active against induced oxidative damage in neuroblastoma IMR32 cells. The extract was found to contain quercetin and other phytochemicals; however, the individual role of phytochemicals was not elaborated [168]. The vegetable extracts of Vernonia amygdalina Delile and Struchium sparganophora L. Kuntze. were found to show neuroprotective properties. This activity was attributed to stimulation of $\mathrm{Na}^{+} / \mathrm{K}^{+}$ ATPase activity, inhibition of $5^{\prime}$-nucleotidase, acetylcholinesterase, butyrylcholinesterase, and monoamine oxidase activities, as well as $\mathrm{Fe}^{2+}$, induced oxidative stress [169]. Quercetin was found active against D-galactose-induced neurotoxicity in mice, as reported by Dong et al. [170]. The presented results stated that quercetin was able to prevent changes in the neuronal cell morphology with Nrf2, HO-1, and SOD expression along with hippocampus. In vitro studies reported by Aluani et al. [171], chitosan-based quercetin nanoparticles exhibited neuroprotective activity. The quercetin in zein nanoparticles was observed to be a potential candidate for oral treatment of Alzheimer's disease [172]. Gupta et al. [173] evaluated the protective effect of quercetin in cadmium-induced cognitive deficits in rats. They hypothesized that cadmium-induced neurotoxicity could be modulated by quercetin via molecular targets involved in brain cholinergic signaling. The continuous treatment of quercetin for 30 days in mice improved the learning and memory loss induced by amyloid $\beta$ (A $\beta$ )-peptide exposure. Thus, it was hypothesized that quercetin could be used as a treatment of neurological disorders [174]. Alzheimer's and Parkinson's disease, both neurological disorders, were hypothesized to be treated by extracts of edible plants Veronica teucrium L. and Veronica jacquinii Baumg methanol extracts containing quercetin and its derivatives as reported by Živković et al. [175]. The reduction in enzymes such as acetylcholinesterase (AChE) and tyrosinase (TYR) concentration after extract treatment led to such a hypothesis. Quercetin has been found in sea buckthorn (Hippophae rhamnoides L.) leaves, along with other phytochemicals. The ethyl acetate fraction containing these phytochemicals has been found active and increased the viability and membrane integrity of neuronal PC-12 cells [176]. Quercetin was found to increase the cell viability in PC-12 cells, along with a reduction in lactate dehydrogenase (LDH) after exposure to hydrogen peroxide, further reducing the apoptosis of PC-12 cells and hippocampal neurons were reported by Bao et al. [177] thus hypothesizing its role as new potential anti-neurodegenerative agent, particularly towards the neurodegeneration due to oxidative stress. An in vivo study in rats for 1-Methy-4-phenyl-1,2,3,6-tetrahydropyridine (MPTP)-induced neurotoxicity by quercetin in combination with piperine at different doses was studied by Singh et al. [178]. The reported results revealed that this combination was quite active in terms of antioxidant and anti-inflammatory properties as the activity of quercetin was further boosted by the presence of piperine; furthermore, quercetin, along with piperine, showed resilient neuroprotective effects once MPTP neurotoxicity was induced in Wistar rats [178]. The ethyl acetate fractionated alcoholic extract of Allium cepa Lam. containing quercetin was studied for diabetic neuropathy in Sprague Dawley rats. The significant neuroprotective effect was observed after 14 days of quercetin administration against streptozotocin-induced diabetic neuropathy [179]. Alligator weed (Alternanthera philoxeroides (Mart.) Griseb.) extracts were also found rich in quercetin along with other phytochemicals as reported by Khamphukdee et al. [180] and their neuroprotective role was also stated by reporting anti-anxiety property in mice through estrogenic activity. Similarly, Carpobrotus edulis L. extracts containing quercetin were found to inhibit acetylcholinesterase $(\mathrm{AChE})$ and butyrylcholinesterase $(\mathrm{BuChE})$, which were able to reduce hydrogen peroxide $\left(\mathrm{H}_{2} \mathrm{O}_{2}\right)$-induced injury in the 
human dopaminergic cell line SH-SY5Y as reported by Rocha et al. [181]. In a similar study, flowers of Reynoutria sachalinensis F. (Schmidt.) Nakai. contained quercetin neuroprotective activity as revealed by Eom et al. [182]. Ay et al. [183], in their detailed study, explained the role of quercetin and hypothesized that the cell survival signaling axis was activated by PKD1-Akt using quercetin, which can be a potential candidate for clinical use in treating PD. Among many phytochemicals obtained from Potentilla parvifolia Fisch. (Rosaceae), quercetin exhibited better neuroprotective effects as reflected by Western blot and morphology analysis [184]. Vegetables such as cabbage (Brassica oleracea var. capitata L.) and cucumber (Cucumis sativus L.) were subjected to aqueous extraction, and in vitro enzymatic activity of acetylcholinesterase, butyryl-cholinesterase, and monoamine oxidase was inhibited. It was hypothesized that these vegetables could be used to treat neurodegeneration and were stated as probable sources of functional foods and nutraceuticals for the management of Alzheimer's diseases [185]. Gynostemma laxum Wall. Cogn. containing quercetin has shown neuroprotective activities and was suggested a natural antioxidant supplement, but Seo et al. [186] have warned further in-depth in vivo investigation. The erythropoietin levels were studied in traumatic brain injury in a rat model, and its levels were unaltered by the use of quercetin, thus justifying its neuroprotective role [187]. Quercetin was used to inhibit acid-sensing ion channels (ASICs), which are associated with neuronal death during ischemic stroke, epileptic seizure, and nociception, as reported by Mukhopadhyay et al. [188]. With the help of computational analysis, they were able to prove the inhibitory effect of quercetin on ASICs and suggested that further in vivo studies are possibly required to show that quercetin can target ASICs. The crossing of the blood-brain barrier (BBB) along with rescuing degenerated neurons, acting on Alzheimer's disease quercetin was loaded into colloidal formulation symbolled as RMP-7-Lf-QU-LS by Kuo and Tsao [189], where RMP-7 is a bradykinin analog, lactoferrin (Lf), quercetin (QU), and liposomes (LS). The results revealed that this colloidal formulation was effective in overcoming BBB to prevent $A \beta$-induced neurodegeneration and can be used to manage Alzheimer's disease in proposing future clinical applications. Quercetin was used to check the memory impairment and deterioration of the cholinergic system in rats with an acquired or genetic disorder of having high levels of lipids in the bloodstream. The increased level of AChE activity in such rats suggested that quercetin can prevent memory impairment and change lipid metabolism [190]. In a similar study, the restoration of acetylcholinesterase activity, an increase of redox status, and lipid peroxidation inhibition in the brain of rats were controlled by the use of quercetin in manganese-induced neurotoxicity [191]. The quercetin and its metabolite quercetin-3-O-glucuronide were able to control neural stem cell viability as reported by Baral et al. [192] during an in vivo and in vitro study via contrary regulation of protein kinase $B(\mathrm{Akt})$. They presented results wherein it was revealed that the reported mechanism suggests quercetin metabolite to possess therapeutic potential in treating neurodegenerative ailments. Quercetin was found effective against sodium fluoride-induced neurotoxicity in rats, as confirmed by Mesram et al. by evaluating biochemical, behavioral, and histopathological parameters [193]. Mehta et al. [194] found quercetin effective in improving memory dysfunction and rescued neurons from chronic unpredicted stress-mediated damage. The molecular mechanism of quercetin showing anticonvulsive behavior was studied in a mouse model by Moghbelinejad et al. [195]. The results revealed that GABAA $\alpha 5$ receptor, which controls the inhibitory signaling in the central nervous system, was probably responsible for this anticonvulsive behavior of quercetin, and a further mode of action was warned for further in-depth studies. Salicornia herbacea $\mathrm{L}$. extracts possessing quercetin were found to provide a neuroprotective effect via regulating the expression of antioxidant proteins (Nrf2) facilitated introduction of antioxidant enzymes [196]. The quercetin-protected hippocampal CA1 pyramidal neurons from ischemic injury was studied by Chen et al. [197], who established their role in providing resilient neuroprotective effects against transient cerebral ischemia by increasing the expression of antioxidant enzymes. Quercetin, in combination with donepezil, enhances cognitive memory in rats by reducing AchE, $\beta$ amyloid1-42 level in the rat brain [198]. The 
quercetin was able to protect neuronal damage in the retina of diabetic rats by improving BDNF, NGF, TrkB, synaptophysin, Akt, Bcl-2, cytochrome c, and caspase-3 expression using Western blotting techniques [199]. The Wistar rats were given quercetin supplementation for evaluating neuroprotective effects such as a decrease in neuronal and glial body areas along with a reduction in neuronal and glial density [200]. Quercetin and its nanocrystal at different concentrations were given orally to rats and increased behavioral indexes along with the anticipation of anxiogenic-like behavior in them [201]. Eggplant (Solanum melongena L.) extract containing quercetin was evaluated for its neuroprotective activity against 6-hydroxydopamine induced in the Parkinsonian rat model [202]. Based on these reports, quercetin used for neuroprotective use has been tremendously covered. The main mechanism is either focus on enzymatic reaction, animal models, and dose dependency. These studies can infer the strongest use of quercetin as a future drug for neurogenerative diseases. The source of quercetin is of utter importance, although that obtained from flora, including vegetables and fruits, to support a circular economy, more plant waste, particularly food waste, should be exploited as a quercetin source. Some recent studies highlighting the role of quercetin as a neuroprotective agent are depicted in Table 2.

Table 2. Some recent reports on the role of quercetin as a neuroprotective agent.

\begin{tabular}{|c|c|c|}
\hline Role & Mode & Reference \\
\hline Antioxidant and AChE inhibitory activity & In vitro and in vivo & [203] \\
\hline $\begin{array}{l}\text { To prevent the increase in AChE activity in the brain, } \\
\text { improve the memory and anxiety-like behavior }\end{array}$ & In vivo & [204] \\
\hline Proteasome activities & In vitro & [205] \\
\hline $\begin{array}{l}\text { Against oxidation-induced neuronal necrotic-such as } \\
\text { cell death }\end{array}$ & In vitro & [206] \\
\hline $\begin{array}{l}\text { Modulation of neuroinflammation and the } \\
\text { cholinergic system }\end{array}$ & In vivo & [207] \\
\hline $\begin{array}{c}\text { Neuronal autophagy and brain injury model by activation } \\
\text { of PI3K/Akt signaling pathway }\end{array}$ & In vivo & [208] \\
\hline Endoplasmic reticulum stress and neuronal cells & In vitro & [209] \\
\hline $\begin{array}{l}\text { Reduced oxidative/nitrative damage to DNA, lipids, and } \\
\text { proteins of neuroblastoma cell line (SH-SY5Y) cell }\end{array}$ & In vitro & [210] \\
\hline $\begin{array}{c}\text { Improves ischemia/reperfusion-induced cognitive } \\
\text { deficits. Inhibition of ASK1/JNK3/caspase-3 Akt } \\
\text { signaling pathway }\end{array}$ & In vitro & [211] \\
\hline Prevention of brain damage by acrylamide & In vivo & [212] \\
\hline $\begin{array}{l}\text { Inhibition of } \mu \text {-calpain protein in hypoxia-induced } \\
\text { neuronal injury }\end{array}$ & In vitro & [213] \\
\hline Autophagy-modulating, Parkinson's diseases & In vivo & [214] \\
\hline $\begin{array}{c}\text { Deprivation and restoration of oxygen/glucose, increased } \\
\text { the expression of Nrf2 }\end{array}$ & In vitro & [215] \\
\hline Neuronal death prevention & In vivo & [216] \\
\hline Anti-convulsant & In vivo & [217] \\
\hline $\begin{array}{l}\text { Inhibition of monoamine oxidase (MAO), AChE, and } \\
\text { BChE activities }\end{array}$ & In vitro & [218] \\
\hline Antioxidative insult & In vivo & [219] \\
\hline Cerebroprotective action & In vivo & [220] \\
\hline $\begin{array}{l}\text { Prevention of okadaic-acid-induced injury by MAPK and } \\
\text { PI3K/Akt/GSK3 } \beta \text { signaling pathways }\end{array}$ & In vitro & [221] \\
\hline Reduction of oxaliplatin-induced oxidative stress in brain & In vitro and in vivo & [222] \\
\hline
\end{tabular}


Table 2. Cont.

\begin{tabular}{|c|c|c|}
\hline Role & Mode & Reference \\
\hline Reduction of immunoreactivity of degenerating neurons & In vivo & [223] \\
\hline Parkinson's disease & In vivo & [224] \\
\hline Apoptosis on neural cells via PI3K/Akt signal pathway & In vitro & [225] \\
\hline Cerebrovascular disorders & In vivo & [226] \\
\hline Alzheimer's disease (AD) prevention & In vivo & [227] \\
\hline $\begin{array}{l}\text { Defense of oxidative Stress via PKC- } \epsilon \\
\text { inactivation/ERK1/2 activation }\end{array}$ & In vivo & [228] \\
\hline Neuropathic pain reliever & In vitro & [229] \\
\hline $\begin{array}{l}\text { Inhibiting oxidative stress and inflammation in } \\
\text { brain injury }\end{array}$ & In vivo & [230] \\
\hline Hypoxic-ischemic brain injury & In vivo & [231] \\
\hline Alzheimer's disease prevention & In vitro & [232] \\
\hline Anti-neuroinflammatory & In vitro & [233] \\
\hline Enhanced neuronal mitochondrial performance & In vitro & [234] \\
\hline Brain therapy, hypoxia & In vivo & [235] \\
\hline $\begin{array}{l}\text { Anti-inflammatory, antioxidant, and } \\
\text { anti-acetylcholinesterase activities in }\end{array}$ & In vitro & [236] \\
\hline $\begin{array}{l}\text { Reduction in oxidative-stress-mediated } \\
\text { neurodegeneration }\end{array}$ & In vivo & [237] \\
\hline Prevention of Parkinson's disease by gene expression & In vitro & [238] \\
\hline $\begin{array}{l}\text { Anti-brain ischemic/reperfusion injury using } \\
\text { Akt pathway }\end{array}$ & In vivo & [239] \\
\hline In neuron survival & In vitro & [240] \\
\hline Cognitive function & In vivo & [241] \\
\hline Antioxidative stress, neuronal damage, & In vivo & [242] \\
\hline Protection of human brain cells & In vitro & {$[243]$} \\
\hline Spatial memory dysfunctions improvement & In vivo & [244] \\
\hline Protection of cognitive and emotional functions & In vivo & {$[245]$} \\
\hline $\begin{array}{c}\text { Reduction of cell apoptosis of oxidant-stressed } \\
\text { neuroblastoma (SK-N-MC) cells }\end{array}$ & In vitro & [246] \\
\hline $\begin{array}{l}\text { Protects the weakening of memory and } \\
\text { anxiogenic behavior }\end{array}$ & In vitro & [247] \\
\hline Locomotor activities, neurotransmission & In vivo & {$[248]$} \\
\hline Spinal cord injury treatment & In vitro & [249] \\
\hline Perinatal cerebral hypoxia-ischemia & In vivo & [250] \\
\hline Protection from oxidative stress and brain edema & In vivo & [251] \\
\hline Brain protection & In vivo and in vitro & [252] \\
\hline Retinal neuroprotection & In vivo & [253] \\
\hline Brain injury treatment & In vivo & {$[254]$} \\
\hline Neurolemmocytes damage prevention & In vivo & [255] \\
\hline Protection of PC12 neural cells & In vitro & [256] \\
\hline $\begin{array}{l}\text { Multiple therapeutic molecular targets of } \\
\text { Alzheimer diseases }\end{array}$ & In vitro & [257] \\
\hline
\end{tabular}


Table 2. Cont.

\begin{tabular}{|c|c|c|}
\hline Role & Mode & Reference \\
\hline Reduction of neuroinflammatory response, antidepressant & In vivo & [258] \\
\hline $\begin{array}{l}\text { Prevention of hippocampal nerve damage, improved } \\
\text { memory function }\end{array}$ & In vivo & [259] \\
\hline Neuron density & In vivo & [260] \\
\hline Prevention of chemical hypoxia & In vitro & [261] \\
\hline Inhibition of glutamate release & In vitro & [262] \\
\hline Anxiolytic effects & In vivo & [263] \\
\hline Ectoenzymes and acetylcholinesterase activities & In vivo & [264] \\
\hline $\begin{array}{l}\text { Increases levels of mitochondrial enzyme (PON2) in } \\
\text { brain cells }\end{array}$ & In vivo & [265] \\
\hline $\begin{array}{l}\text { Nerve protection via Nrf-2/HO-1 activation and } \\
\text { NF-kB inhibition }\end{array}$ & In vivo & [266] \\
\hline $\begin{array}{c}\text { Catalepsy normalization, improvement of } \\
\text { neurochemical parameters }\end{array}$ & In vivo & [267] \\
\hline $\begin{array}{l}\text { Suppression of cellular acetylcholinesterase (AChE), } \\
\text { protection against oxidative stress }\end{array}$ & In vitro & [268] \\
\hline $\begin{array}{l}\text { Preventive medicine for polychlorinated biphenyls } \\
\text { (PCBs)-induced neurotoxicity }\end{array}$ & In vivo & [269] \\
\hline Cerebral ischemia-reperfusion injury treatment & In vivo & [270] \\
\hline Protection against induced neurobehavioral impairments & In vivo & [271] \\
\hline $\begin{array}{l}\text { Neuroprotection in mitochondrial neurotoxin-induced } \\
\text { Parkinson diseases }\end{array}$ & In vivo & [272] \\
\hline $\begin{array}{c}\text { Neurovascular coupling protection, decrease in } \\
\text { neurovascular oxidation }\end{array}$ & In vivo & [273] \\
\hline Neuronal protection & In vivo & [274] \\
\hline Neuroprotection against brain oxidative stress & In vivo & [275] \\
\hline Against neuron death & In vivo & [276] \\
\hline Against neurotoxic venoms & In vitro & [277] \\
\hline $\begin{array}{l}\text { Neurodegeneration protection via production of } \\
\text { ROS scavenging }\end{array}$ & In vivo & [278] \\
\hline Neuroprotection in ypoxic-ischemic brain injury & In vivo & [279] \\
\hline Neuroprotection in duodenum enteric nervous system & In vivo & [280] \\
\hline Alcoholic neuropathy protection & In vivo & [281] \\
\hline $\begin{array}{l}\text { Protection in cerebral ischemia through activation of } \\
\text { BDNF-TrkB-PI3K/Akt signaling pathway }\end{array}$ & In vivo & [282] \\
\hline Prevention of oxidative stress in brain & In vivo & [283] \\
\hline $\begin{array}{c}\text { Reversal of hypobaric hypoxia, neuroprotective } \\
\text { response stimulant }\end{array}$ & In vivo & [284] \\
\hline Diabetic neuropathy prevention & In vivo & [285] \\
\hline Prevention of oxidative damage by induced neurotoxicity & In vitro & [286] \\
\hline Prevention of cerebral ischemia-induced oxidative stress & In vivo & [287] \\
\hline Neuroinflammation prevention & In vitro & [288] \\
\hline Cerebral ischemia protection & In vitro & [289] \\
\hline Protection Oxidative injury P19 neurons & In vitro & [290] \\
\hline
\end{tabular}


Table 2. Cont.

\begin{tabular}{ccc}
\hline Role & Mode & Reference \\
\hline Lutamate-induced neurotoxicity protection in HT22 cells & In vitro & {$[291]$} \\
\hline Neuron cell protection & In vitro & {$[292]$} \\
\hline Oxidative stress & In vivo & {$[293]$} \\
\hline $\begin{array}{c}\text { Decreases the neuronal damage and scavenged free } \\
\text { radicals }\end{array}$ & In vivo & {$[294]$} \\
\hline Protection for cerebral ischemic conditions & In vivo & {$[295]$} \\
\hline Neurodegeneration protection & In vivo & {$[296]$} \\
\hline
\end{tabular}

\section{Quercetin from Food Industry Wastes and By-Products}

Food industries, mainly post-fruits and vegetable processing, generate a massive amount of waste/byproducts, which are usually discarded as landfilling or are subjected to composting and incineration, which remains a common process of waste disposal. Managing this type of waste/byproduct is vital, especially to reduce environmental pollution. However, it is worth noting that this cheap source of raw material occurring as waste/byproducts can be a worthy source of bioactive compounds such as quercetin, exhibiting rich bioactivities. These bioactives obtained have been explored for their antioxidant, anti-microbial, anti-tumor activities, as well as have been recommended to be used as a natural coloring and a preservative agent in different industries (such as in pharmaceuticals, cosmetics, and food industries). Though a wide range of compounds has been obtained, in the present context, our focus remains on quercetin obtained from vegetal wastes. Quercetin has been obtained from apple and plum pomace [297-299] as well as from the peel wastes of banana, kiwi, tomato, and guava fruits [300-303]. Skin wastes of onion and garlic have been reported as a good source of polyphenolic compounds such as quercetin, which was shown to exhibit certain bioactivities [304-306]. Besides, quercetin has been isolated from the peels of different citrus varieties [307]. Polyphenolic compounds such as gallic, vanillic, syringic, and ferulic acids and $p$-coumaric derivatives along with flavonoids such as those of quercetin and its derivatives have been obtained from the 'lees' generated post 'pisco' production process [308]. Among the fruit seed wastes, grape seeds are reported to be rich in polyphenols, resveratrol, quercetin, and other flavonoid compounds, which are confirmed to impart cardiovascular protective effects [309]. In papaya seeds, quercetin and quercetin 3-O-glycoside have been isolated [310]. Furthermore, seeds of Theobroma grandiflorum (a tree related to cacao) are reported to be a rich source of bioactive sulfated flavonoid glycosides, quercetin, quercetin 3-O-D-glucuronide, and other polyphenolic compounds [311]. Quercetin and isoquercetin have been obtained from the mango seed kernel, too [312].

On another note, among various types of leaves studied, quercetin-3-O-(6"-feruloyl)- $\beta$-Dgalactopyranoside was obtained from guava plants leaves (Psidium guajava L.), which demonstrated rich bioactives [313], while quercetin-3-O-rutinoside, quercetin-3-orobinobioside and quercetin-3-O-galactoside were isolated from chokeberry leaves $[314,315]$ In the cranberry leaves (+)-catechin, procyanidin B1, (-)-epicatechin have been isolated [314]. From the quince leaves, quercetin-3-O-galactoside, quercetin-3-O-rutinoside have been obtained $[314,316]$. On another note, elderberry (Sambucus nigra L.) branch wastes have been explored to obtain quercetin and its glycoconjugate derivatives [317]. Residues obtained from broccoli-processing industries (stalks and florets) have been explored to obtain glucosinolate, polyphenols, and flavonoids such as quercetin [318]. Cauliflower wastes extracts (stems and leaves) are also reported to contain high amounts of flavonoid glycosides, mainly derived from quercetin and kaempferol [319,320]. Apart from fresh produce waste, quercetin has been reported in other wastes such as sugarcane (Saccharum officinarum L.), bagasse [321,322], acerola (Malpighia emarginata DC.), flour bagasse [323], stalks of Euonymus alatus (Thunb.) Sieb. [324], and peanut shells [325]. With the available informa- 
tion in the scientific databases, it is quite evident that food industrial wastes/byproducts (mainly those of fruits and vegetables based) hold high scope for obtaining quercetin. The food waste/byproducts containing quercetin by the amount reported in recent years are summarized in Table 3.

Table 3. Quercetin in food industrial wastes and byproducts.

\begin{tabular}{ccc}
\hline Waste/By-Products & Quantity $\mathbf{( m g / g )}{ }^{*}$ & Reference \\
\hline Tomato peels & $9.97 \pm 0.27$ & {$[326]$} \\
\hline Berry peel & $0.0001 \pm 0.00$ & {$[327]$} \\
\hline Lotus byproducts & (Only detected not quantified) & {$[328]$} \\
\hline Coppery onion outer dry layers & $52.84 \pm 0.12$ & {$[329]$} \\
\hline Red grape pomace & $0.05 \pm 0.00$ & {$[330]$} \\
\hline Cacao beans pod husk & $0.6018 \pm 0.0112$ & {$[331]$} \\
\hline Grape pomace & $0.03189 \pm 0.00277$ & {$[332]$} \\
\hline Grape pomace & $0.24923 \pm 0.00114$ & {$[333]$} \\
\hline Onion waste & (A case study of industrial scale, & {$[334]$} \\
\hline $\begin{array}{c}\text { output yield is in Kgs) } \\
\text { Black currant residue with quercetin } \\
\text { glycoside (based on the place of cultivation) }\end{array}$ & $34.6 \pm 5.7$ & {$[335]$} \\
\hline${ }^{*}$ The units presented are converted to (mg/g) as compared to different units reported in the references.
\end{tabular}

\section{Conclusions}

The tremendous effort by researchers to bring attention to the importance of quercetin as a cardioprotective and neuroprotective agent has led to a new milestone in discovering it as a potential therapeutical candidate. The sustainable resources from plant sources, in particular, vegetables, have added value to this research. A paradigm shift is needed to utilize food waste or food byproducts as a continued sustainable resource of this secondary metabolite. The main challenge in tabulating quercetin as a cardioprotective and neuroprotective agent is the diversion of demand from fresh resources to non-utilized food waste. However, other challenges, such as the specific targeted delivery of quercetin and its understanding of the cellular metabolism of quercetin derivatives, need a more interdisciplinary approach. The use of nano-particulate quercetin can be carried out in the future based on the sources of origin, which in turn can increase the bioavailability of quercetin at the drug-targeted site for cardiovascular and neurological diseases. The cellular mechanism, targeted delivery, and above all effectiveness, of quercetin in treating cardioprotective and neuroprotective diseases has been remarkably covered by researchers; however, the quercetin sources from fresh fruits and vegetables and synthetic methods are needed to be diverted to food wastes or byproducts. Further research is also required to identify the purity of quercetin, its safety efficacy, and meet the standard regulations of governing bodies (e.g., EU legislation). Thus, this review warrants further extensive research activities to be undertaken to obtain quercetin from underexplored plant produce (e.g., vegetables and fruits) as well as food-industry processing wastes and byproducts, mainly originating from fruits and vegetables.

Author Contributions: I.U.H.B. collecting literature, writing, original draft preparation and editing; R.B. writing and editing. Both authors have read and agreed to the published version of the article.

Funding: This review articles theme is based on the ongoing VALORTECH project (ERA-Chair in Food (By-)Products Valorisation Technologies), which has received funding from the European Union's Horizon 2020 Research and Innovation Program under grant agreement No 810630.

Institutional Review Board Statement: Not applicable.

Informed Consent Statement: Not applicable. 


\section{Data Availability Statement: Not applicable.}

Conflicts of Interest: The authors declare no conflict of interest.

\section{References}

1. Kelly, G.S. Quercetin. Altern. Med. Rev. 2011, 16, 172-195.

2. Wang, G.; Li, Y.; Lei, C.; Lei, X.; Zhu, X.; Yang, L.; Zhang, R. Quercetin exerts antidepressant and cardioprotective effects in estrogen receptor $\alpha$-deficient female mice via BDNF-AKT/ERK1/2 signaling. J. Steroid Biochem. Mol. Biol. 2021, $206,105795$. [CrossRef] [PubMed]

3. Sengul, E.; Gelen, V.; Gedikli, S. Cardioprotective activities of quercetin and rutin in sprague dawley rats treated with 5fluorouracil. J. Anim. Plant Sci. 2021, 31, 423-431.

4. Lesjak, M.; Beara, I.; Simin, N.; Pintać, D.; Majkić, T.; Bekvalac, K.; Orčić, D.; Mimica-Dukić, N. Antioxidant and anti-inflammatory activities of quercetin and its derivatives. J. Funct. Foods 2018, 40, 68-75. [CrossRef]

5. Davis, J.M.; Murphy, A.; Carmichael, M.D.; Davis, B. Quercetin increases brain and muscle mitochondrial biogenesis and exercise tolerance. Am. J. Physiol. Regul. Integr. Comp. Physiol. 2009, 296, R1071-R1077. [CrossRef]

6. Saeedi-Boroujeni, A.; Mahmoudian-Sani, M.-R. Anti-inflammatory potential of Quercetin in COVID-19 treatment. J. Inflamm. 2021, 18, 1. [CrossRef] [PubMed]

7. Hussain, S.; Jõudu, I.; Bhat, R. Dietary Fiber from Underutilized Plant Resources-A Positive Approach for Valorization of Fruit and Vegetable Wastes. Sustainability 2020, 12, 5401. [CrossRef]

8. Jõgi, K.; Bhat, R. Valorization of food processing wastes and by-products for bioplastic production. Sustain. Chem. Pharm. 2020, 18, 100326. [CrossRef]

9. Malenica, D.; Bhat, R. Current research trends in fruit and vegetables wastes and by-products management-Scope and opportunities in the Estonian context. Agron. Res. 2020, 18, 1760-1795.

10. Sharma, M.; Bhat, R. Extraction of Carotenoids from Pumpkin Peel and Pulp: Comparison between Innovative Green Extraction Technologies (Ultrasonic and Microwave-Assisted Extractions Using Corn Oil). Foods 2021, 10, 787. [CrossRef]

11. Ay, M.; Charli, A.; Jin, H.; Anantharam, V.; Kanthasamy, A.; Kanthasamy, A.G. Quercetin. In Book Nutraceuticals, Ramesh C. Gupta, 1st ed.; Academic Press; Elsevier: New York, NY, USA, 2016; Volume 32, pp. 447-452.

12. Yu, S.; Kim, S.R.; Jiang, K.; Ogrodnik, M.; Zhu, X.Y.; Ferguson, C.M.; Tchkonia, T.; Lerman, A.; Kirkland, J.L.; Lerman, L.O. Quercetin Reverses Cardiac Systolic Dysfunction in Mice Fed with a High-Fat Diet: Role of Angiogenesis. Oxid Med. Cell. Longev. 2021, 2021, 8875729. [CrossRef]

13. Rolnik, A.; Żuchowski, J.; Stochmal, A.; Olas, B. Quercetin and kaempferol derivatives isolated from aerial parts of Lens culinaris Medik as modulators of blood platelet functions. Ind. Crop. Prod. 2020, 152, 112536. [CrossRef]

14. Elbarbry, F.; Abdelkawy, K.; Moshirian, N.; Abdel-Megied, A.M. The antihypertensive effect of quercetin in young spontaneously hypertensive rats; role of arachidonic acid metabolis. Int. J. Mol. Sci. 2020, 21, 6554. [CrossRef]

15. Liang, Y.; Zhang, Y.; Liu, M.; Han, X.; Zhang, J.; Zhang, X.; Chu, L. Protective effect of quercetin against myocardial ischemia as a $\mathrm{Ca}^{2+}$ channel inhibitor: Involvement of inhibiting contractility and $\mathrm{Ca}^{2+}$ influx via L-type $\mathrm{Ca}^{2+}$ channels. Arch. Pharm. Res. 2020, 43, 808-820. [CrossRef] [PubMed]

16. Song, X.; Zhao, Y.; Wang, S.; Wang, Y.; Chen, Q.; Zhao, H.; Wang, H.; Tian, S.; Yu, H.; Wu, Z. Zi Shen Huo Luo Formula Enhances the Therapeutic Effects of Angiotensin-Converting Enzyme Inhibitors on Hypertensive Left. Ventricular Hypertrophy by Interfering with Aldosterone Breakthrough and Affecting Caveolin-1/Mineralocorticoid Receptor Colocalization and Downstream Extracellular Signal-Regulated Kinase Signaling. Front. Pharmacol. 2020, 11, 383.

17. Lu, J.; Meng, Y.; Wang, R.; Zhang, R. Anti-arrhythmogenic effects of quercetin postconditioning in myocardial ischemia/reperfusion injury in a rat model. J. King Saud Univ. Sci. 2020, 32, 1910-1916. [CrossRef]

18. Ferenczyova, K.; Kalocayova, B.; Bartekova, M. Potential implications of quercetin and its derivatives in cardioprotection. Int. J. Mol. Sci. 2020, 21, 1585. [CrossRef]

19. Ferenczyova, K.; Kalocayova, B.; Kindernay, L.; Jelemensky, M.; Balis, P.; Berenyiova, A.; Zemancikova, A.; Farkasova, V.; Sykora, M.; Tothova, L.; et al. quercetin exerts age-dependent beneficial effects on blood pressure and vascular function, but is inefficient in preventing myocardial ischemia-reperfusion injury in zucker diabetic fatty rats. Molecules 2020, 25, 187. [CrossRef]

20. Wang, M.-N.; Cao, Y.-G.; Wei, Y.-X.; Ren, Y.-J.; Liu, Y.-L.; Chen, X.; He, C.; Zheng, X.-K.; Feng, W.-S. Saffloflavone, a new flavonoid from the flowers of Carthamus tinctorius L. and its cardioprotective activity. Nat. Prod. Res. 2020, 12, 1-6.

21. Stechyshyn, I.; Pavliuk, B. The quercetine containing drugs in pharmacological correction of experimental diabetes with myocardial injury. Rom. J. Diabetes Nutr. Metab. Dis. 2020, 26, 393-399. [CrossRef]

22. Binder, P.; Wang, S.; Radu, M.; Zin, M.; Collins, L.; Khan, S.; Li, Y.; Sekeres, K.; Humphreys, N.; Swanton, E.; et al. Pak2 as a Novel Therapeutic Target for Cardioprotective Endoplasmic Reticulum Stress Response. Circ. Res. 2019, 124, 696-711. [CrossRef] [PubMed]

23. Ogar, I.; Egbung, G.E.; Nna, V.U.; Atangwho, I.J.; Itam, E.H. Hyptis verticillata attenuates dyslipidaemia, oxidative stress and hepato-renal damage in streptozotocin-induced diabetic rats. Life Sci. 2019, 219, 283-293. [CrossRef] [PubMed]

24. Burak, C.; Wolffram, S.; Zur, B.; Langguth, P.; Fimmers, R.; Alteheld, B.; Stehle, P.; Egert, S. Effect of alpha-linolenic acid in combination with the flavonol Quercetin on markers of cardiovascular disease risk in healthy, non-obese adults: A randomized, double-blinded placebo-controlled crossover trial. Nutrition 2019, 58, 47-56. [CrossRef] 
25. Shu, Z.; Yang, Y.; Yang, L.; Jiang, H.; Yu, X.; Wang, Y. Cardioprotective effects of dihydro quercetin against ischemia reperfusion injury by inhibiting oxidative stress and endoplasmic reticulum stress-induced apoptosis: Via the PI3K/Akt pathway. Food Funct. 2019, 10, 213-215. [CrossRef]

26. Wang, Y.; Xie, X.; Liu, L.; Zhang, H.; Ni, F.; Wen, J.; Wu, Y.; Wang, Z.; Xiao, W. Four new flavonol glycosides from the leaves of Ginkgo biloba. Nat. Prod. Res. 2019. [CrossRef]

27. Chakraborty, M.; Ahmed, M.G.; Bhattacharjee, A. Effect of quercetin on myocardial potency of curcumin against ischemia reperfusion induced myocardial toxicity. Synergy 2018, 7, 25-29. [CrossRef]

28. Chiş, I.C.; Baltaru, D.; Dumitrovici, A.; Coseriu, A.; Radu, B.C.; Moldovan, R.; Mureşan, A. Protective effects of quercetin from oxidative/nitrosative stress under intermittent hypobaric hypoxia exposure in the rat's heart. Physiol. Int. 2018, 105, 233-246. [CrossRef]

29. Zakaria, N.; Khalil, S.R.; Awad, A.; Khairy, G.M. Quercetin Reverses Altered Energy Metabolism in the Heart of Rats Receiving Adriamycin Chemotherapy. Cardiovasc. Toxicol. 2018, 18, 109-119. [CrossRef]

30. Zhang, X.; Li, P.; Guo, S.; Wang, S.; Liu, D. Quantitation of $\beta$-carboline and quercetin in alligator weed (Alternanthera philoxeroides (Mart.) Griseb.) by LC-MS/MS and evaluation of cardioprotective effects of the methanol extracts. Drug Discov. Ther. 2018, 12, 341-346. [CrossRef] [PubMed]

31. Castillo, R.L.; Herrera, E.A.; Gonzalez-Candia, A.; Reyes-Farias, M.; De La Jara, N.; Peña, J.P.; Carrasco-Pozo, C. Quercetin Prevents Diastolic Dysfunction Induced by a High-Cholesterol Diet: Role of Oxidative Stress and Bioenergetics in Hyperglycemic Rats. Oxidative Med. Cell. Longev. 2018, 2018, 7239123. [CrossRef]

32. Hayamizu, K.; Morimoto, S.; Nonaka, M.; Hoka, S.; Sasaguri, T. Cardiotonic actions of quercetin and its metabolite tamarixetin through a digitalis-like enhancement of $\mathrm{Ca}^{2+}$ transients. Arch. Biochem. Biophys. 2018, 637, 40-47. [CrossRef] [PubMed]

33. Garjani, A.; Tila, D.; Hamedeyazdan, S.; Vaez, H.; Rameshrad, M.; Pashaii, M.; Fathiazad, F. An investigation on cardioprotective potential of Marrubium vulgare aqueous fraction against ischaemia-reperfusion injury in isolated rat heart. Folia Morphol. 2017, 76, 361-371. [CrossRef]

34. Alrushaid, S.; Zhao, Y.; Sayre, C.L.; Maayah, Z.H.; Laird Forrest, M.; Senadheera, S.N.; Chaboyer, K.; Anderson, H.D.; El-Kadi, A.O.S.; Davies, N.M. Mechanistically elucidating the in vitro safety and efficacy of a novel doxorubicin derivative. Drug Deliv. Transl. Res. 2017, 7, 582-597. [CrossRef]

35. Li, W.; Li, Y.; Sun, R.; Zhou, S.; Li, M.; Feng, M.; Xie, Y. Dual character of flavonoids in attenuating and aggravating ischemiareperfusion-induced myocardial injury. Exp. Ther. Med. 2017, 14, 1307-1314. [CrossRef] [PubMed]

36. Ballmann, C.; Denney, T.; Beyers, R.J.; Quindry, T.; Romero, M.; Selsby, J.T.; Quindry, J.C. Long-term dietary quercetin enrichment as a cardioprotective countermeasure in mdx mice. Exp. Physiol. 2017, 102, 635-649. [CrossRef] [PubMed]

37. Syama, H.P.; Arya, A.D.; Dhanya, R.; Nisha, P.; Sundaresan, A.; Jacob, E.; Jayamurthy, P. Quantification of phenolics in Syzygium cumini seed and their modulatory role on tertiary butyl-hydrogen peroxide-induced oxidative stress in H9c2 cell lines and key enzymes in cardioprotection. J. Food Sci. Technol. 2017, 54, 2115-2125. [CrossRef]

38. Roslan, J.; Giribabu, N.; Karim, K.; Salleh, N. Quercetin ameliorates oxidative stress, inflammation and apoptosis in the heart of streptozotocin-nicotinamide-induced adult male diabetic rats. Biomed. Pharmacother. 2017, 86, 570-582. [CrossRef]

39. Kumar, M.; Kasala, E.R.; Bodduluru, L.N.; Kumar, V.; Lahkar, M. Molecular and biochemical evidence on the protective effects of quercetin in isoproterenol-induced acute myocardial injury in rats. J. Biochem. Mol. Toxicol. 2017, 31, 8. [CrossRef]

40. Bin-Jaliah, I. Quercetin inhibits chronic stress-Induced myocardial infarction in rats. [La Quercetina inhibe el infarto al miocardio inducido por estrés crónico en ratas]. Int. J. Morphol. 2017, 35, 1363-1369. [CrossRef]

41. Chekalina, N.I.; Shut, S.V.; Trybrat, T.A.; Burmak, Y.H.; Petrov, Y.Y.; Manusha, Y.I.; Kazakov, Y.M. Effect of quercetin on parameters of central hemodynamics and myocardial ischemia in patients with stable coronary heart disease. Wiad. Lek. 2017, 70, 707-711.

42. Ramachandran, R.; Mani, M.; Soman, S. Mediation of FOXO3 gene on momism of quercetin against isoproterenol induced cardiotoxicity in H9C2 cardiomyoblasts. Int. Cardiovasc. Res. J. 2017, 11, 49-54.

43. Soman, S.; Rajamanickam, C.; Rauf, A.A.; Madambath, I. Molecular mechanisms of the antiglycative and cardioprotective activities of Psidium guajava leaves in the rat diabetic myocardium. Pharm. Biol. 2016, 54, 3078-3085. [CrossRef]

44. Cheserek, M.J.; Wu, G.; Li, L.; Li, L.; Karangwa, E.; Shi, Y.; Le, G. Cardioprotective effects of lipoic acid, quercetin and resveratrol on oxidative stress related to thyroid hormone alterations in long-term obesity. J. Nutr. Biochem. 2016, 33, 36-44. [CrossRef]

45. Li, C.; Wang, T.; Zhang, C.; Xuan, J.; Su, C.; Wang, Y. Quercetin attenuates cardiomyocyte apoptosis via inhibition of JNK and p38 mitogen-activated protein kinase signaling pathways. Gene 2016, 577, 275-280. [CrossRef]

46. Grande, F.; Parisi, O.I.; Mordocco, R.A.; Rocca, C.; Puoci, F.; Scrivano, L.; Quintieri, A.M.; Cantafio, P.; Ferla, S.; Brancale, A.; et al. Quercetin derivatives as novel antihypertensive agents: Synthesis and physiological characterization. Eur. J. Pharm. Sci. 2016, 82, 161-170. [CrossRef]

47. Bartekova, M.; Radosinska, J.; Pancza, D.; Barancik, M.; Ravingerova, T. Cardioprotective effects of quercetin against ischemiareperfusion injury are age-dependent. Psychol. Res. 2016, 65, S101-S107. [CrossRef] [PubMed]

48. Kavya, S.; Kumar, M.S. Cardioprotective effect of bioflavonoids against isoproterenol induced cardiotoxicity in rats. Int. J. Pharma Bio Sci. 2016, 7, P158-P162.

49. Dobhal, Y.; Parcha, V.; Dhasmana, D.C. Characterization of new cardioprotective principle isolated from methanolic extract of Allium humile leaves from Himalayan region. Bangladesh J. Pharmacol. 2016, 11, 383-388. [CrossRef] 
50. Liu, X.; Yu, Z.; Huang, X.; Gao, Y.; Wang, X.; Gu, J.; Xue, S. Peroxisome proliferator-activated receptor $\gamma$ (PPAR $\gamma)$ mediates the protective effect of quercetin against myocardial ischemia-reperfusion injury via suppressing the NF- $\mathrm{kB}$ pathway. Am. J. Transl. Res. 2016, 8, 5169-5186.

51. Galinski, C.N.; Zwicker, J.I.; Kennedy, D.R. Revisiting the mechanistic basis of the French Paradox: Red wine inhibits the activity of protein disulfide isomerase in vitro. Thromb. Res. 2016, 137, 169-173. [CrossRef] [PubMed]

52. Ozbek, N.; Bali, E.B.; Karasu, C. Quercetin and hydroxytyrosol attenuates xanthine/xanthine oxidase-induced toxicity in H9c2 cardiomyocytes by regulation of oxidative stress and stress-sensitive signaling pathways. Gen. Physiol. Biophys. 2015, 34, 407-414. [PubMed]

53. Brüll, V.; Burak, C.; Stoffel-Wagner, B.; Wolffram, S.; Nickenig, G.; Müller, C.; Langguth, P.; Alteheld, B.; Fimmers, R.; Naaf, S.; et al. Effects of a quercetin-rich onion skin extract on $24 \mathrm{~h}$ ambulatory blood pressure and endothelial function in overweight-to-obese patients with (pre-)hypertension: A randomised double-blinded placebo-controlled cross-over trial. Br. J. Nutr. 2015, 114, 1263-1277. [CrossRef]

54. Daubney, J.; Bonner, P.L.; Hargreaves, A.J.; Dickenson, J.M. Cardioprotective and cardiotoxic effects of quercetin and two of its in vivo metabolites on differentiated H9c2 cardiomyocytes. Basic Clin. Pharmacol. Toxicol. 2015, 116, 96-109. [CrossRef] [PubMed]

55. Dower, J.I.; Geleijnse, J.M.; Gijsbers, L.; Schalkwijk, C.; Kromhout, D.; Hollman, P.C. Supplementation of the pure flavonoids epicatechin and quercetin affects some biomarkers of endothelial dysfunction and inflammation in (pre)hypertensive adults: A randomized double-blind, placebo-controlled, crossover trial. J. Nutr. 2015, 145, 1459-1463. [CrossRef]

56. Dower, J.I.; Geleijnse, J.M.; Gijsbers, L.; Zock, P.L.; Kromhout, D.; Hollman, P.C.H. Effects of the pure flavonoids epicatechin and quercetin on vascular function and cardiometabolic health: A randomized, double-blind, placebo-controlled, crossover trial. Am. J. Clin. Nutr. 2015, 101, 914-921. [CrossRef]

57. El-Mahalaway, A.M.; Selim, A.A.; Mahboub, F.A.R. The effect of quercetin on cyclosporine-A-induced cardiotoxicity in adult male albino rats: A histological and immunohistochemical study. Egypt. J. Histol. 2015, 38, 464-473. [CrossRef]

58. Daskalova, E.; Delchev, S.; Peeva, Y.; Vladimirova-Kitova, L.; Kratchanova, M.; Kratchanov, C.; Denev, P. Antiatherogenic and Cardioprotective Effects of Black Chokeberry (Aronia melanocarpa) Juice in Aging Rats. Evid. Based Complement. Altern. Med. 2015, 2015, 717439. [CrossRef]

59. Adaramoye, O.A.; Lawal, S.O. Kolaviron, a biflavonoid fraction from Garcinia kola, protects against isoproterenol-induced injury by mitigating cardiac dysfunction and oxidative stress in rats. J. Basic Clin. Physiol. Pharmacol. 2015, 26, 65-72. [CrossRef]

60. Matouk, A.I.; Taye, A.; Heeba, G.H.; El-Moselhy, M.A. Quercetin augments the protective effect of losartan against chronic doxorubicin cardiotoxicity in rats. Environ. Toxicol. Pharmacol. 2013, 36, 443-450. [CrossRef] [PubMed]

61. Milton Prabu, S.; Muthumani, M.; Shagirtha, K. Quercetin potentially attenuates cadmium induced oxidative stress mediated cardiotoxicity and dyslipidemia in rats. Eur. Rev. Med. Pharmacol. Sci. 2013, 17, 582-595.

62. Li, M.; Jiang, Y.; Jing, W.; Sun, B.; Miao, C.; Ren, L. Quercetin provides greater cardioprotective effect than its glycoside derivative rutin on isoproterenol-induced cardiac fibrosis in the rat. Can. J. Physiol. Pharmacol. 2013, 91, 951-959. [CrossRef]

63. Chen, Y.-W.; Chou, H.-C.; Lin, S.-T.; Chen, Y.-H.; Chang, Y.-J.; Chen, L.; Chan, H.-L. Cardioprotective effects of quercetin in cardiomyocyte under ischemia/reperfusion injury. Evid. Based Complement. Altern. Med. 2013. [CrossRef] [PubMed]

64. Wang, S.-Q.; Zhu, X.-F.; Wang, X.-N.; Shen, T.; Xiang, F.; Lou, H.-X. Flavonoids from Malus hupehensis and their cardioprotective effects against doxorubicin-induced toxicity in H9c2 cells. Phytochem 2013, 87, 119-125. [CrossRef]

65. Wang, Y.; Zhang, Z.Z.; Wu, Y.; Ke, J.J.; He, X.H.; Wang, Y.L. Quercetin postconditioning attenuates myocardial ischemia/reperfusion injury in rats through the PI3K/Akt pathway. Braz. J. Med. Biol. Res. 2013, 46, 861-867. [CrossRef] [PubMed]

66. Shen, Y.; Croft, K.D.; Hodgson, J.M.; Kyle, R.; Lee, I.-L.E.; Wang, Y.; Stocker, R.; Ward, N.C. Quercetin and its metabolites improve vessel function by inducing eNOS activity via phosphorylation of AMPK. Biochem. Pharmacol. 2012, 84, 1036-1044. [CrossRef]

67. Yadav, H.N.; Singh, M.; Sharma, P.L. Pharmacological inhibition of GSK-3 $\beta$ produces late phase of cardioprotection in hyperlipidemic rat: Possible involvement of HSP 72. Mol. Cell. Biochem. 2012, 369, 227-233. [CrossRef]

68. Panda, S.; Kar, A.; Banerjee, T.; Sharma, N. Combined effects of quercetin and atenolol in reducing isoproterenol- induced cardiotoxicity in rats: Possible mediation through scavenging free radicals. Cardiovasc. Toxicol. 2012, 12, 235-242. [CrossRef] [PubMed]

69. Nabavi, S.F.; Nabavi, S.M.; Mirzaei, M.; Moghaddam, A.H. Protective effect of quercetin against sodium fluoride induced oxidative stress in rat's heart. Food Funct. 2012, 3, 437-441. [CrossRef] [PubMed]

70. Chen, J.-Y.; Chan, H.-L.; Chou, H.-C. Proteomic analysis of quercetin-induced cardioprotective effects. Genom. Med. Biomark. Health Sci. 2012, 4, 51-53. [CrossRef]

71. Wang, Z.; Wan, H.; Tong, X.; He, Y.; Yang, J.; Zhang, L.; Shao, C.; Ding, Z.; Wan, H.; Li, C. An integrative strategy for discovery of functional compound combination from Traditional Chinese Medicine: Danhong Injection as a model. Biomed Pharm. 2021, 138, 111451. [CrossRef]

72. Santo, G.D.; de Veras, B.O.; Rico, E.; Magro, J.D.; Agostini, J.F.; Vieira, L.D.; Calisto, J.F.F.; Mocelin, R.; de Sá Fonseca, V.; Wanderley, A.G. Hexane extract from SpoSndias mombin L. (Anacardiaceae) prevents behavioral and oxidative status changes on model of Parkinson's disease in zebrafish. Comp. Biochem. Physiol. C Toxicol. Pharmacol. 2021, 241, 108953. [CrossRef] 
73. Bhatia, G.; Singh, J.; Nehru, B. Neuroprotective effects of hydro-alcoholic extract of Eclipta alba against 1-methyl-4phenylpyridinium-induced in vitro and in vivo models of Parkinson's disease. Environ. Sci. Pollut. Res. 2021, 28, 9390-9406. [CrossRef] [PubMed]

74. Shen, H.; Zheng, Y.; Chen, R.; Huang, X.; Shi, G. Neuroprotective effects of Quercetin 3-O-sophoroside from Hibiscus rosa-sinensis Linn. on scopolamine-induced amnesia in mice. J. Funct. Foods 2021, 76, 104291. [CrossRef]

75. Sehaber-Sierakowski, C.C.; Vieira-Frez, F.C.; Hermes-Uliana, C.; Martins, H.A.; Bossolani, G.D.P.; Lima, M.M.; Blegniski, F.P.; Guarnier, F.A.; Baracat, M.M.; Perles, J.V.C.M.; et al. Protective effects of Quercetin-loaded microcapsules on the enteric nervous system of diabetic rats. Auton. Neurosci. Basic Clin. 2021, 230, 102759. [CrossRef] [PubMed]

76. Jalili-Baleh, L.; Nadri, H.; Forootanfar, H.; Küçükkılınç, T.T.; Ayazgök, B.; Sharifzadeh, M.; Rahimifard, M.; Baeeri, M.; Abdollahi, M.; Foroumadi, A.; et al. Chromone-lipoic acid conjugate: Neuroprotective agent having acceptable butyrylcholinesterase inhibition, antioxidant and copper-chelation activities. DARU J. Pharm. Sci. 2021. [CrossRef] [PubMed]

77. Ortega, J.T.; Parmar, T.; Golczak, M.; Jastrzebska, B. Protective effects of flavonoids in acute models of light-induced retinal degeneration. Mol. Pharmacol. 2021, 99, 60-77. [CrossRef]

78. Zhang, J.; Ning, L.; Wang, J. Dietary Quercetin attenuates depressive-like behaviors by inhibiting astrocyte reactivation in response to stress. Biochem. Biophys. Res. Commun. 2020, 533, 1338-1346. [CrossRef] [PubMed]

79. Le, K.; Song, Z.; Deng, J.; Peng, X.; Zhang, J.; Wang, L.; Zhou, L.; Bi, H.; Liao, Z.; Feng, Z. Quercetin alleviates neonatal hypoxic-ischemic brain injury by inhibiting microglia-derived oxidative stress and TLR4-mediated inflammation. J. Inflamm. Res. 2020, 69, 1201-1213. [CrossRef]

80. Baraka, S.M.; Saleh, D.O.; Ghaly, N.S.; Melek, F.R.; Gamal el Din, A.A.; Khalil, W.K.B.; Said, M.M.; Medhat, A.M. Flavonoids from Barnebydendron riedelii leaf extract mitigate thioacetamide-induced hepatic encephalopathy in rats: The interplay of NF- $\mathrm{kB} / \mathrm{IL}-6$ and Nrf2/HO-1 signaling pathways. Bioorg. Chem. 2020, 105, 104444. [CrossRef]

81. Dallas, P.; Rekkas, D.M.; Demetzos, C.; Colombo, G.; Banella, S.; Javornik, U.; Plavec, J.; Mavromoustakos, T.; Tzakos, A.G.; Valsami, G. Preparation and Biophysical Characterization of Quercetin Inclusion Complexes with $\beta$-Cyclodextrin Derivatives to be Formulated as Possible Nose-to-Brain Quercetin Delivery Systems. Mol. Pharm. 2020, 17, 4241-4255.

82. Singh, V.; Shri, R.; Krishan, P.; Singh, I.P.; Shah, P. Isolation and characterization of components responsible for neuroprotective effects of Allium cepa outer scale extract against ischemia reperfusion induced cerebral injury in mice. J. Food Sci. 2020, 85, 4009-4017. [CrossRef] [PubMed]

83. Sahoo, P.K.; Pradhan, L.K.; Aparna, S.; Agarwal, K.; Banerjee, A.; Das, S.K. Quercetin abrogates bisphenol A induced altered neurobehavioral response and oxidative stress in zebrafish by modulating brain antioxidant defence system. Environ. Toxicol. Pharmacol. 2020, 80, 103483. [CrossRef] [PubMed]

84. Liu, Y.; Zhu, D.; Luo, J.; Chen, X.; Gao, L.; Liu, W.; Chen, T. NIR-II-Activated Yolk-Shell Nanostructures as an Intelligent Platform for Parkinsonian Therapy. ACS Appl. Bio Mater. 2020, 3, 6876-6887. [CrossRef]

85. Rifaai, R.A.; Mokhemer, S.A.; Saber, E.A.; El-Aleem, S.A.A.; El-Tahawy, N.F.G. Neuroprotective effect of Quercetin nanoparticles: A possible prophylactic and therapeutic role in alzheimer's disease. J. Chem. Neuroanat. 2020, 107, 101795. [CrossRef]

86. Wang, Y.-Y.; Chang, C.-Y.; Lin, S.-Y.; Wang, J.-D.; Wu, C.-C.; Chen, W.-Y.; Kuan, Y.-H.; Liao, S.-L.; Wang, W.-Y.; Chen, C.-J. Quercetin protects against cerebral ischemia/reperfusion and oxygen glucose deprivation/reoxygenation neurotoxicity. J. Nutr. Biochem. 2020, 83, 108436. [CrossRef]

87. Martins-Perles, J.V.C.; Bossolani, G.D.P.; Zignani, I.; de Souza, S.R.G.; Frez, F.C.V.; de Souza Melo, C.G.; Barili, E.; de Souza Neto, F.P.; Guarnier, F.A.; Armani, A.L.C.; et al. Quercetin increases bioavailability of nitric oxide in the jejunum of euglycemic and diabetic rats and induces neuronal plasticity in the myenteric plexus. Auton. Neurosci. 2020, 227, 102675. [CrossRef]

88. An, L.; Zhang, W.; Ma, G.; Wang, K.; Ji, Y.; Ren, H.; Wang, Y. Neuroprotective effects of Camellia nitidissima Chi leaf extract in hydrogen peroxide-treated human neuroblastoma cells and its molecule mechanisms. Food Sci. Nutr. 2020, 8, $4782-4793$. [CrossRef]

89. Sharma, L.; Sharma, A.; Goyal, R.; Alam, J. Pinus Roxburghii Sarg. Ameliorates alzheimer's disease-type neurodegeneration and cognitive deficits caused by intracerebroventricular-streptozotocin in rats: An in vitro and in vivo study. Indian J. Pharm. Sci. 2020, 82, 861-870. [CrossRef]

90. Karaman, M.; Tesanovic, K.; Novakovic, A.; Jakovljevic, D.; Janjusevic, L.; Sibul, F.; Pejin, B. Coprinus comatus filtrate extract, a novel neuroprotective agent of natural origin. Nat. Prod. Res. 2020, 34, 2346-2350. [CrossRef]

91. Pakrashi, S.; Chakraborty, J.; Bandyopadhyay, J. Neuroprotective Role of Quercetin on Rotenone-Induced Toxicity in SH-SY5Y Cell Line Through Modulation of Apoptotic and Autophagic Pathways. Neurochem. Res. 2020, 45, 1962-1973. [CrossRef]

92. Xie, J.; Song, W.; Liang, X.; Zhang, Q.; Shi, Y.; Liu, W.; Shi, X. Protective effect of Quercetin on streptozotocin-induced diabetic peripheral neuropathy rats through modulating gut microbiota and reactive oxygen species level. Biomed. Pharmacother. 2020, 127, 110147. [CrossRef]

93. Chaturvedi, S.; Malik, M.Y.; Rashid, M.; Singh, S.; Tiwari, V.; Gupta, P.; Shukla, S.; Singh, S.; Wahajuddin, M. Mechanistic exploration of Quercetin against metronidazole induced neurotoxicity in rats: Possible role of nitric oxide isoforms and inflammatory cytokines. NeuroToxicology 2020, 79, 1-10. [CrossRef]

94. Pinheiro, R.G.R.; Granja, A.; Loureiro, J.A.; Pereira, M.C.; Pinheiro, M.; Neves, A.R.; Reis, S. RVG29-Functionalized Lipid Nanoparticles for Quercetin Brain Delivery and Alzheimer's Disease. Pharm. Res. 2020, 37, 139. [CrossRef] [PubMed] 
95. Nzekoue, F.K.; Angeloni, S.; Navarini, L.; Angeloni, C.; Freschi, M.; Hrelia, S.; Vitali, L.A.; Sagratini, G.; Vittori, S.; Caprioli, G. Coffee silverskin extracts: Quantification of 30 bioactive compounds by a new HPLC-MS/MS method and evaluation of their antioxidant and antibacterial activities. Food Res. Int. 2020, 133, 109128. [CrossRef]

96. de Mattos, B.D.S.; Soares, M.S.P.; Spohr, L.; Pedra, N.S.; Teixeira, F.C.; de Souza, A.A.; Stefanello, F.M.; Baldissarelli, J.; Gamaro, G.D.; Spanevello, R.M. Quercetin prevents alterations of behavioral parameters, delta-aminolevulinic dehydratase activity, and oxidative damage in brain of rats in a prenatal model of autism. Int. J. Dev. Neurosci. 2020, 80, 287-302. [CrossRef] [PubMed]

97. Lossi, L.; Merighi, A.; Novello, V.; Ferrandino, A. Protective effects of some grapevine polyphenols against naturally occurring neuronal death. Molecules 2020, 25, 2925. [CrossRef]

98. Pinheiro, R.G.R.; Granja, A.; Loureiro, J.A.; Pereira, M.C.; Pinheiro, M.; Neves, A.R.; Reis, S. Quercetin lipid nanoparticles functionalized with transferrin for Alzheimer's disease. Eur. J. Pharm. Sci. 2020, 148, 105314.

99. Viswanatha, G.L.; Drishya, M.; Kishore, D.V.; Shylaja, H.; Moolemath, Y. Characterization and Anti-stroke Activity of Stem Extract of Colebrookea oppositifolia Smith. J. Biol. Act. Prod. Nat. 2020, 10, 250-263. [CrossRef]

100. Gugliandolo, E.; Peritore, A.F.; D'amico, R.; Licata, P.; Crupi, R. Evaluation of neuroprotective effects of Quercetin against aflatoxin b1-intoxicated mice. Animals 2020, 10, 898. [CrossRef]

101. Woo, Y.; Lim, J.S.; Oh, J.; Lee, J.S.; Kim, J.-S. Neuroprotective effects of euonymus alatus extract on scopolamine-induced memory deficits in mice. Antioxidants 2020, 9, 449. [CrossRef] [PubMed]

102. Yang, S.; Zhou, H.; Wang, G.; Zhong, X.-H.; Shen, Q.-L.; Zhang, X.-J.; Li, R.-Y.; Chen, L.-H.; Zhang, Y.-H.; Wan, Z. Quercetin is protective against short-term dietary advanced glycation end products intake induced cognitive dysfunction in aged ICR mice. $J$. Food Biochem. 2020, 44, 4. [CrossRef] [PubMed]

103. Yang, S.; Wang, G.; Ma, Z.F.; Qin, L.-Q.; Zhai, Y.-J.; Yu, Z.-L.; Xue, M.; Zhang, Y.-H.; Wan, Z. DietaryAdvanced Glycation End Products-Induced Cognitive Impairment in Aged ICR Mice: Protective Role of quercetin. Mol. Nutr. Food Res. 2020, 64, 1901019. [CrossRef]

104. Ibrahim, K.A.; Eleyan, M.; Abd El-Rahman, H.A.; Khwanes, S.A.; Mohamed, R.A. Quercetin Attenuates the Oxidative InjuryMediated Upregulation of Apoptotic Gene Expression and Catecholaminergic Neurotransmitters of the Fetal Rats' Brain Following Prenatal Exposure to Fenitrothion Insecticide. Neurotox. Res. 2020, 37, 871-882. [CrossRef]

105. Shalavadi, M.H.; Chandrashekhar, V.M.; Muchchandi, I.S. Neuroprotective effect of Convolvulus pluricaulis Choisy in oxidative stress model of cerebral ischemia reperfusion injury and assessment of MAP2 in rats. J. Ethnopharmacol. 2020, $249,112393$. [CrossRef] [PubMed]

106. Vieira-Frez, F.C.; Sehaber-Sierakowski, C.C.; Perles, J.V.C.M.; Bossolani, G.D.P.; Verri, W.A., Jr.; Nascimento, R.C.D.; Guarnier, F.A.; Bordini, H.P.; Blegniski, F.P.; Martins, H.A.; et al. Anti- and pro-oxidant effects of Quercetin stabilized by microencapsulation on interstitial cells of Cajal, nitrergic neurons and M2-like macrophages in the jejunum of diabetic rats. NeuroToxicology 2020, 77, 193-204. [CrossRef]

107. Hu, T.; Lu, X.-Y.; Shi, J.-J.; Liu, X.-Q.; Chen, Q.-B.; Wang, Q.; Chen, Y.-B.; Zhang, S.-J. Quercetin protects against diabetic encephalopathy via SIRT1/NLRP3 pathway in $\mathrm{db} / \mathrm{db}$ mice. J. Cell. Mol. Med. 2020, 24, 3449-3459. [CrossRef]

108. Park, D.-J.; Kang, J.-B.; Shah, F.-A.; Jin, Y.-B.; Koh, P.-O. Quercetin Attenuates Decrease of Thioredoxin Expression Following Focal Cerebral Ischemia and Glutamate-induced Neuronal Cell Damage. Neuroscience 2020, 428, 38-49. [CrossRef]

109. Sharma, S.; Raj, K.; Singh, S. Neuroprotective Effect of Quercetin in Combination with Piperine Against Rotenone- and Iron Supplement-Induced Parkinson's Disease in Experimental Rats. Neurotox. Res. 2020, 37, 198-209. [CrossRef]

110. Gül, Ş.; Aydoğmuş, E.; Bahadir, B.; Büyükuysal, Ç.; Güven, B. Neuroprotective effects of Quercetin on cerebral vasospasm following experimental subarachnoid haemorrhage in rats. Turk. J. Med. Sci. 2020, 50, 1106-1110. [CrossRef] [PubMed]

111. Zubčić, K.; Radovanović, V.; Vlainić, J.; Hof, P.R.; Oršolić, N.; Šimić, G.; Jazvinšćak Jembrek, M. PI3K/Akt and ERK1/2 Signalling Are Involved in Quercetin-Mediated Neuroprotection against Copper-Induced Injury. Oxid. Med. Cell. Longev. 2020, 9834742. [CrossRef]

112. Huang, C.; Fu, C.; Qi, Z.-P.; Guo, W.-L.; You, D.; Li, R.; Zhu, Z. Localised delivery of Quercetin by thermo-sensitive PLGAPEG-PLGA hydrogels for the treatment of brachial plexus avulsion. Artif. Cells Nanomed. Biotechnol. 2020, 48, 1010-1021. [CrossRef]

113. Yu, X.; Li, Y.; Mu, X. Effect of Quercetin on PC12 Alzheimer's Disease Cell Model Induced by A $\beta$ 25-35 and Its Mechanism Based on Sirtuin1/Nrf2/HO-1 Pathway. Biomed. Res. Int. 2020, 2020, 8210578.

114. Moujahed, S.; Ruiz, A.; Hallegue, D.; Sakly, M. Quercetin alleviates styrene oxide-induced cytotoxicity in cortical neurons in vitro via modulation of oxidative stress and apoptosis. Drug Chem. Toxicol. 2020, 1-9. [CrossRef]

115. Sallam, A.; Mira, A.; Sabry, M.A.; Abdel-Halim, O.B.; Gedara, S.R.; Galala, A.A. New prenylated flavonoid and neuroprotective compounds from Tephrosia purpurea subsp. Dunensis. Nat. Prod. Res. 2020, 1-9. [CrossRef] [PubMed]

116. Qi, Y.; Guo, L.; Jiang, Y.; Shi, Y.; Sui, H.; Zhao, L. Brain delivery of Quercetin-loaded exosomes improved cognitive function in AD mice by inhibiting phosphorylated tau-mediated neurofibrillary tangles. Drug Deliv. 2020, 27, 745-755. [CrossRef] [PubMed]

117. Malik, J.; Kaur, S.; Karan, M.; Choudhary, S. Neuroprotective effect of standardized extracts of three Lactuca sativa Linn. varieties against 3-NP induced Huntington's disease like symptoms in rats. Nutr. Neurosci. 2020. [CrossRef]

118. Gao, H.; Yuan, X.; Wang, Z.; Gao, Q.; Yang, J. Profiles and neuroprotective effects of Lycium ruthenicum polyphenols against oxidative stress-induced cytotoxicity in PC12 cells. J. Food Biochem. 2020, 44, 1. [CrossRef] [PubMed] 
119. Lee, B.; Yeom, M.; Shim, I.; Lee, H.; Hahm, D.-H. Protective Effects of Quercetin on Anxiety-Like Symptoms and Neuroinflammation Induced by Lipopolysaccharide in Rats. Evid. Based Compl. Altern. Med. 2020. [CrossRef]

120. Debnath, K.; Jana, N.R.; Jana, N.R. Quercetin Encapsulated Polymer Nanoparticle for Inhibiting Intracellular Polyglutamine Aggregation. ACS Appl. Bio Mater. 2019, 2, 5298-5305. [CrossRef]

121. Piovezana Bossolani, G.D.; Silva, B.T.; Colombo Martins Perles, J.V.; Lima, M.M.; Vieira Frez, F.C.; Garcia de Souza, S.R.; SehaberSierakowski, C.C.; Bersani-Amado, C.A.; Zanoni, J.N. Rheumatoid arthritis induces enteric neurodegeneration and jejunal inflammation, and Quercetin promotes neuroprotective and anti-inflammatory actions. Life Sci. 2019, 238, 116956. [CrossRef]

122. Jamali-Raeufy, N.; Baluchnejadmojarad, T.; Roghani, M.; Keimasi, S.; Goudarzi, M. Isorhamnetin exerts neuroprotective effects in STZ-induced diabetic rats via attenuation of oxidative stress, inflammation and apoptosis. J. Chem. Neuroanat. 2019, 102, 101709. [CrossRef]

123. Donoso, F.; Ramírez, V.T.; Golubeva, A.V.; Moloney, G.M.; Stanton, C.; Dinan, T.G.; Cryan, J.F. Naturally Derived Polyphenols Protect Against Corticosterone-Induced Changes in Primary Cortical Neurons. Int. J. Neuropsychopharmacol. 2019, 22, 765-777. [CrossRef]

124. Kwon, S.-H.; Lee, S.R.; Park, Y.J.; Ra, M.; Lee, Y.; Pang, C.; Kim, K.H. Suppression of 6-hydroxydopamine-induced oxidative stress by hyperoside via activation of nrf2/ho-1 signaling in dopaminergic neurons. Int. J. Mol. Sci. 2019, 20, 5832. [CrossRef]

125. Nielsen, B.E.; Bermudez, I.; Bouzat, C. Flavonoids as positive allosteric modulators of $\alpha 7$ nicotinic receptors. Neuropharmacology 2019, 160, 107794. [CrossRef] [PubMed]

126. Wang, C.; Guo, T.-L.; Shen, L.-X. Research on estrogen-like protective effect of Quercetin on PC12 cells induced by A $\beta 25.35$ and molecular mechanism. Chin. Pharm. J. 2019, 35, 1558-1564.

127. Gapski, A.; Gomes, T.M.; Bredun, M.A.; Ferreira-Lima, N.E.; Ludka, F.K.; Bordignon-Luiz, M.T.; Burin, V.M. Digestion behavior and antidepressant-like effect promoted by acute administration of blueberry extract on mice. Food Res. Int. 2019, 125, 108618. [CrossRef] [PubMed]

128. Moliner, C.; Barros, L.; Dias, M.I.; Reigada, I.; Ferreira, I.C.F.R.; López, V.; Langa, E.; Rincón, C.G. Viola cornuta and Viola $\times$ wittrockiana: Phenolic compounds, antioxidant and neuroprotective activities on Caenorhabditis elegans. J. Food Drug Anal. 2019, 27, 849-859. [CrossRef] [PubMed]

129. Azib, L.; Debbache-Benaida, N.; Costa, G.D.; Atmani-Kilani, D.; Saidene, N.; Ayouni, K.; Richard, T.; Atmani, D. Pistacia lentiscus L. leaves extract and its major phenolic compounds reverse aluminium-induced neurotoxicity in mice. Ind. Crops. Prod. 2019, 137, 576-584. [CrossRef]

130. Li, Y.; Tian, Q.; Li, Z.; Dang, M.; Lin, Y.; Hou, X. Activation of Nrf2 signaling by sitagliptin and Quercetin combination against $\beta$-amyloid induced Alzheimer's disease in rats. Drug Dev. Res. 2019, 80, 837-845. [CrossRef] [PubMed]

131. Wu, M.; Liu, F.; Guo, Q. Quercetin attenuates hypoxia-ischemia induced brain injury in neonatal rats by inhibiting TLR4/NF-kB signaling pathway. Int. Immunopharmacol. 2019, 74, 105704. [CrossRef]

132. Fereidouni, S.; Kumar, R.R.; Chadha, V.D.; Dhawan, D.K. Quercetin plays protective role in oxidative induced apoptotic events during chronic chlorpyrifos exposure to rats. J. Biochem. Mol. Toxicol. 2019, 33, 8. [CrossRef] [PubMed]

133. Martínez-Busi, M.; Arredondo, F.; González, D.; Echeverry, C.; Vega-Teijido, M.A.; Carvalho, D.; Rodríguez-Haralambides, A.; Rivera, F.; Dajas, F.; Abin-Carriquiry, J.A. Purification, structural elucidation, antioxidant capacity and neuroprotective potential of the main polyphenolic compounds contained in Achyrocline satureioides (Lam) D.C. (Compositae). Bioorg. Med. Chem. 2019, 27, 2579-2591. [CrossRef]

134. Yan, R.; Tian, H.; Du, Z. Quercetin protects PC-12 cells against hypoxia injury by downregulation of miR-122. Iran. J. Basic Med. Sci. 2019, 22, 391-398. [PubMed]

135. Cittadini, M.C.; Repossi, G.; Albrecht, C.; Di Paola Naranjo, R.; Miranda, A.R.; de Pascual-Teresa, S.; Soria, E.A. Effects of bioavailable phenolic compounds from Ilex paraguariensis on the brain of mice with lung adenocarcinoma. Phytother. Res. 2019, 33, 1142-1149. [CrossRef]

136. Kaur, S.; Singla, N.; Dhawan, D.K. Neuro-protective potential of quercetin during chlorpyrifos induced neurotoxicity in rats. Drug Chem. Toxicol. 2019, 42, 220-230. [CrossRef]

137. Lu, Y.; Du, Y.; Qin, X.; Wu, H.; Huang, Y.; Cheng, Y.; Wei, Y. Comprehensive evaluation of effective polyphenols in apple leaves and their combinatory antioxidant and neuroprotective activities. Ind. Crop. Prod. 2019, 129, 242-252. [CrossRef]

138. Chatterjee, J.; Langhnoja, J.; Pillai, P.P.; Mustak, M.S. Neuroprotective effect of Quercetin against radiation-induced endoplasmic reticulum stress in neurons. J. Biochem. Mol. Toxicol. 2019, 33, e22242. [CrossRef]

139. Haq, S.H.; AlAmro, A.A. Neuroprotective effect of Quercetin in murine cortical brain tissue cultures. Clin. Nutr. Exp. 2019, 23, 89-96. [CrossRef]

140. Faggi, L.; Porrini, V.; Lanzillotta, A.; Benarese, M.; Mota, M.; Tsoukalas, D.; Parrella, E.; Pizzi, M. A polyphenol-enriched supplement exerts potent epigenetic-protective activity in a cell-based model of brain ischemia. Nutrients 2019, 11, 345. [CrossRef]

141. Viswanatha, G.L.; Venkataranganna, M.V.; Prasad, N.B.L.; Shylaja, H. Achyranthes aspera Linn. alleviates cerebral ischemiareperfusion-induced neurocognitive, biochemical, morphological and histological alterations in Wistar rats. J. Ethnopharmacol. 2019, 228, 58-69. [CrossRef]

142. Park, D.-J.; Kang, J.-B.; Shah, M.-A.; Koh, P.-O. Quercetin alleviates the injury-induced decrease of protein phosphatase 2A subunit B in cerebral ischemic animal model and glutamate-exposed HT22 cells. J. Vet. Med. Sci. 2019, 81, 1047-1054. [CrossRef] 
143. Jing, B.-Q.; Zhao, L.; Jing, W.; Zhang, Y.-X. The neuroprotective effects of Quercetin on hypoxic-ischemic brain injury in neonatal mice. Lat. Am. J. Pharm. 2019, 38, 651-658.

144. Ocal, O.; Borcek, A.O.; Pasaoglu, O.; Gundogdu, A.C.; Kaplanoglu, G.T.; Baykaner, M.K. Can Quercetin be an option for treatment of spinal cord injury? An experimental study. Turk. Neurosurg. 2019, 29, 247-253. [CrossRef] [PubMed]

145. Kumar, A.; Mehta, V.; Raj, U.; Varadwaj, P.K.; Udayabanu, M.; Yennamalli, R.M.; Singh, T.R. Computational and in-vitro validation of natural molecules as potential acetylcholinesterase inhibitors and neuroprotective agents. Curr. Alzheimer Res. 2019, 16, 116-127. [CrossRef]

146. Sinha, S.; Kumar, B.; Luqman, S.; Singh, D.K. Neuroprotective potential of Cucurbita maxima Duchesne ex Poir, Caeselpenia bunduc (L.) Roxb and Bombax ceiba Linn extracts. S. Afr. J. Bot. 2019, 120, 319-325. [CrossRef]

147. Zhang, Y.; Wu, Y.-N.; Wang, W.; Yao, G.-D.; Jiang, X.-F.; Song, S.-J. Flavones from a natural tea (the leaves of Armeniaca sibirica L.) prevent oxidative stress-induced neuronal death. J. Food Biochem. 2018, 42, 1-7. [CrossRef]

148. Zhu, X.; Cheng, Y.-Q.; Lu, Q.; Du, L.; Yin, X.-X.; Liu, Y.-W. Enhancement of glyoxalase 1, a polyfunctional defense enzyme, by quercetin in the brain in streptozotocin-induced diabetic rats. Naunyn Schmiedeberg Arch. Pharmacol. 2018, 391, 1237-1245. [CrossRef] [PubMed]

149. Woo, M.; Kim, M.J.; Song, Y.O. Bioactive compounds in Kimchi improve the cognitive and memory functions impaired by amyloid beta. Nutrients 2018, 10, 1554. [CrossRef]

150. Jembrek, M.J.; Vlainić, J.; Čadez, V.; Segota, S. Atomic force microscopy reveals new biophysical markers for monitoring subcellular changes in oxidative injury: Neuroprotective effects of quercetin at the nanoscale. PLoS ONE 2018, 13, e0200119.

151. Enteshari Najafabadi, R.; Kazemipour, N.; Esmaeili, A.; Beheshti, S.; Nazifi, S. Using superparamagnetic iron oxide nanoparticles to enhance bioavailability of quercetin in the intact rat brain. BMC Pharmacol. Toxicol. 2018, 19, 59. [CrossRef]

152. Viswanatha, G.L.; Venkataranganna, M.V.; Prasad, N.B.L.; Hanumanthappa, S. Chemical characterization and cerebroprotective effect of methanolic root extract of Colebrookea oppositifolia in rats. J. Ethnopharmacol. 2018, 223, 63-75. [CrossRef]

153. Ghaffari, F.; Moghaddam, A.H.; Zare, M. Neuroprotective effect of quercetin nanocrystal in a 6-hydroxydopamine model of Parkinson disease: Biochemical and behavioral evidence. Basic Clin. Neurosci. 2018, 9, 317-324. [CrossRef] [PubMed]

154. Singh, S.; Kumar, P. Piperine in combination with quercetin halt 6-OHDA induced neurodegeneration in experimental rats: Biochemical and neurochemical evidences. Neurosci. Res. 2018, 133, 38-47. [CrossRef]

155. Kale, A.; Pişkin, O.; Baş, Y.; Aydln, B.G.; Can, M.; Elmas, Ö.; Büyükuysal, Ç. Neuroprotective effects of quercetin on radiationinduced brain injury in rats. J. Radiat. Res. 2018, 59, 404-410. [CrossRef] [PubMed]

156. Omar, S.H.; Scott, C.J.; Hamlin, A.S.; Obied, H.K. Biophenols: Enzymes ( $\beta$-secretase, Cholinesterases, histone deacetylase and tyrosinase) inhibitors from olive (Olea europaea L.). Fitoterapia 2018, 128, 118-129. [CrossRef]

157. Du, G.; Zhao, Z.; Chen, Y.; Li, Z.; Tian, Y.; Liu, Z.; Liu, B.; Song, J. Quercetin protects rat cortical neurons against traumatic brain injury. Mol. Med. Rep. 2018, 17, 7859-7865. [CrossRef]

158. Ghahremani, S.; Soodi, M.; Atashi, A. quercetin ameliorates chlorpyrifos-induced oxidative stress in the rat brain: Possible involvment of PON2 pathway. J. Food Biochem. 2018, 42, 3. [CrossRef]

159. Oliveira, A.I.; Pinho, C.; Fonte, P.; Sarmento, B.; Dias, A.C.P. Development, characterization, antioxidant and hepatoprotective properties of poly( $\varepsilon$-caprolactone) nanoparticles loaded with a neuroprotective fraction of Hypericum perforatum. Int. J. Biol. Macromol. 2018, 110, 185-196. [CrossRef] [PubMed]

160. Park, D.-J.; Shah, F.-A.; Koh, P.-O. Quercetin attenuates neuronal cells damage in a middle cerebral artery occlusion animal model. J. Vet. Med. Sci. 2018, 80, 676-683. [CrossRef] [PubMed]

161. Türedi, S.; Yuluğ, E.; Alver, A.; Bodur, A.; İnce, İ. A morphological and biochemical evaluation of the effects of quercetin on experimental sciatic nerve damage in rats. Exp. Ther. Med. 2018, 15, 3215-3224. [PubMed]

162. Wang, D.; Zhao, J.; Li, S.; Shen, G.; Hu, S. quercetin attenuates domoic acid-induced cognitive deficits in mice. Nutr. Neurosci. 2018, 21, 123-131. [CrossRef] [PubMed]

163. Li, X.; Wang, H.; Wen, G.; Li, L.; Gao, Y.; Zhuang, Z.; Zhou, M.; Mao, L.; Fan, Y. Neuroprotection by quercetin via mitochondrial function adaptation in traumatic brain injury: PGC-1 $\alpha$ pathway as a potential mechanism. J. Cell. Mol. Med. 2018, 22, 883-891. [CrossRef] [PubMed]

164. Rahvar, M.; Owji, A.A.; Mashayekhi, F.J. Effect of quercetin on the brain-derived neurotrophic factor gene expression in the rat brain. Bratisl. Med. J. 2018, 119, 28-31. [CrossRef]

165. Ghosh, S.; Sarkar, S.; Choudhury, S.T.; Ghosh, T.; Das, N. Triphenyl phosphonium coated nano-quercetin for oral delivery: Neuroprotective effects in attenuating age related global moderate cerebral ischemia reperfusion injury in rats. Nanomed. Nanotechnol. Biol. Med. 2017, 13, 2439-2450. [CrossRef]

166. Godoy, J.A.; Lindsay, C.B.; Quintanilla, R.A.; Carvajal, F.J.; Cerpa, W.; Inestrosa, N.C. Quercetin Exerts Differential Neuroprotective Effects Against $\mathrm{H}_{2} \mathrm{O}_{2}$ and $\mathrm{A} \beta$ Aggregates in Hippocampal Neurons: The Role of Mitochondria. Mol. Neurobiol. 2017, 54, 7116-7128. [CrossRef] [PubMed]

167. Soares, J.J.; Rodrigues, D.T.; Gonçalves, M.B.; Lemos, M.C.; Gallarreta, M.S.; Bianchini, M.C.; Gayer, M.C.; Puntel, R.L.; Roehrs, R.; Denardin, E.L.G. Paraquat exposure-induced Parkinson's disease-like symptoms and oxidative stress in Drosophila melanogaster: Neuroprotective effect of Bougainvillea glabra Choisy. Biomed. Pharmacother. 2017, 95, 245-251. [CrossRef]

168. Bhatia, G.; Dhuna, V.; Dhuna, K.; Kaur, M.; Singh, J. Bacopa monnieri extracts prevent hydrogen peroxide-induced oxidative damage in a cellular model of neuroblastoma IMR32 cells. Chin. J. Nat. Med. 2017, 15, 834-846. [CrossRef] 
169. Ademosun, A.O.; Oboh, G.; Oyeleye, S.I.; Ejakpovi, I.I.; Adewuni, T.M. Modulation of cholinergic, monoaminergic, and purinergic enzymes of the brain functions by bitter (Vernonia amygdalina) and water bitter (Struchium sparganophora) leaves extracts: Comparison of phenolic constituents versus nootropic potentials. Comp. Clin. Path. 2017, 26, 1267-1272. [CrossRef]

170. Dong, F.; Wang, S.; Wang, Y.; Yang, X.; Jiang, J.; Wu, D.; Qu, X.; Fan, H.; Yao, R. Quercetin ameliorates learning and memory via the Nrf2-ARE signaling pathway in D-galactose-induced neurotoxicity in mice. Biochem. Biophys. Res. Commun. 2017, 491, 636-641. [CrossRef]

171. Aluani, D.; Tzankova, V.; Yordanov, Y.; Kondeva-Burdina, M.; Yoncheva, K. In vitro protective effects of encapsulated Quercetin in neuronal models of oxidative stress injury. Biotechnol. Biotechnol. Equip. 2017, 31, 1055-1063. [CrossRef]

172. Moreno, L.C.G.E.I.; Puerta, E.; Suárez-Santiago, J.E.; Santos-Magalhães, N.S.; Ramirez, M.J.; Irache, J.M. Effect of the oral administration of nanoencapsulated quercetin on a mouse model of Alzheimer's disease. Int. J. Pharm. 2017, 517, 50-57. [CrossRef] [PubMed]

173. Gupta, R.; Shukla, R.K.; Chandravanshi, L.P.; Srivastava, P.; Dhuriya, Y.K.; Shanker, J.; Singh, M.P.; Pant, A.B.; Khanna, V.K. Protective Role of quercetin in Cadmium-Induced Cholinergic Dysfunctions in Rat Brain by Modulating Mitochondrial Integrity and MAP Kinase Signaling. Mol. Neurobiol. 2017, 54, 4560-4583. [CrossRef]

174. Li, Y.-L.; Guo, H.; Zhao, Y.-Q.; Li, A.-F.; Ren, Y.-Q.; Zhang, J.-W. Quercetin protects neuronal cells from oxidative stress and cognitive degradation induced by amyloid $\beta$-peptide treatment. Mol. Med. Rep. 2017, 16, 1573-1577. [CrossRef]

175. Živković, J.Č.; Barreira, J.C.M.; Šavikin, K.P.; Alimpić, A.Z.; Stojković, D.S.; Dias, M.I.; Santos-Buelga, C.; Duletić-Laušević, S.N.; Ferreira, I.C.F.R. Chemical Profiling and Assessment of Antineurodegenerative and Antioxidant Properties of Veronica teucrium L. and Veronica jacquinii Baumg. Chem. Biodivers. 2017, 14, e1700167. [CrossRef]

176. Cho, C.H.; Jang, H.; Lee, M.; Kang, H.; Heo, H.J.; Kim, D.-O. Sea buckthorn (Hippophae rhamnoides L.) leaf extracts protect neuronal PC-12 cells from oxidative stress. J. Microbiol. Biotechnol. 2017, 27, 1257-1265. [CrossRef]

177. Bao, D.; Wang, J.; Pang, X.; Liu, H. Protective Effect of quercetin against Oxidative Stress-Induced Cytotoxicity in Rat Pheochromocytoma (PC-12) Cells. Molecules 2017, 22, 1122. [CrossRef] [PubMed]

178. Singh, S.; Jamwal, S.; Kumar, P. Neuroprotective potential of quercetin in combination with piperine against 1-methyl-4-phenyl1,2,3,6-tetrahydropyridine-induced neurotoxicity. Neural Regen. Res. 2017, 12, 1137-1144. [PubMed]

179. Dureshahwar, K.; Mubashir, M.; Une, H. Quantification of quercetin obtained from Allium cepa Lam. leaves and its effects on streptozotocin-induced diabetic neuropathy. Pharmacogn. Res. 2017, 9, 287-293.

180. Khamphukdee, C.; Chulikhit, Y.; Daodee, S.; Monthakantirat, O. Potential of Alternanthera philoxeroides on improvement of anxiety-like behavior induced by ovariectomized mice model. Indian J. Pharm. Educ. Res. 2017, 51, S494-S497. [CrossRef]

181. Rocha, M.I.; Rodrigues, M.J.; Pereira, C.; Pereira, H.; da Silva, M.M.; da Neng, N.R.; Nogueira, J.M.F.; Varela, J.; Barreira, L.; Custódio, L. Biochemical profile and in vitro neuroprotective properties of Carpobrotus edulis L., a medicinal and edible halophyte native to the coast of South Africa. S. Afr. J. Bot. 2017, 111, 222-231. [CrossRef]

182. Eom, M.R.; Weon, J.B.; Jung, Y.S.; Ryu, G.H.; Yang, W.S.; Ma, C.J. Neuroprotective compounds from Reynoutria sachalinensis. Arch. Pharm. Res. 2017, 40, 704-712. [CrossRef] [PubMed]

183. Ay, M.; Luo, J.; Langley, M.; Jin, H.; Anantharam, V.; Kanthasamy, A.; Kanthasamy, A.G. Molecular mechanisms underlying protective effects of quercetin against mitochondrial dysfunction and progressive dopaminergic neurodegeneration in cell culture and MitoPark transgenic mouse models of Parkinson's Disease. J. Neurochem. 2017, 141, 766-782. [CrossRef]

184. Yuan, Z.; Luan, G.; Wang, Z.; Hao, X.; Li, J.; Suo, Y.; Li, G.; Wang, H. Flavonoids from Potentilla parvifolia Fisch. and Their Neuroprotective Effects in Human Neuroblastoma SH-SY5Y Cells in vitro. Chem. Biodivers. 2017, 14, e1600487. [CrossRef]

185. Oboh, G.; Ademiluyi, A.O.; Ogunsuyi, O.B.; Oyeleye, S.I.; Dada, A.F.; Boligon, A.A. Cabbage and cucumber extracts exhibited anticholinesterase, antimonoamine oxidase and antioxidant properties. J. Food Biochem. 2017, 41, e12358. [CrossRef]

186. Seo, J.Y.; Kim, S.K.; Nguyen, P.H.; Lee, J.Y.; Tung, P.H.T.; Sung, S.H.; Oh, W.K. Chemical constituents from a Gynostemma laxum and their antioxidant and neuroprotective activities. Chin. Med. 2017, 12, 15. [CrossRef] [PubMed]

187. Kalemci, O.; Aydin, H.E.; Kizmazoglu, C.; Kaya, I.; Yılmaz, H.; Arda, N.M. Effects of Quercetin and mannitol on erythropoietin levels in rats following acute severe traumatic brain injury. J. Korean Neurosurg. Soc. 2017, 60, 355-361. [CrossRef] [PubMed]

188. Mukhopadhyay, M.; Singh, A.; Sachchidanand, S.; Bera, A.K. Quercetin inhibits acid-sensing ion channels through a putative binding site in the central vestibular region. Neuroscience 2017, 348, 264-272. [CrossRef]

189. Kuo, Y.-C.; Tsao, C.-W. Neuroprotection against apoptosis of SK-N-MC cells using RMP-7- and lactoferrin-grafted liposomes carrying quercetin. Int. J. Nanomed. 2017, 12, 2857-2869. [CrossRef] [PubMed]

190. Braun, J.B.S.; Ruchel, J.B.; Adefegha, S.A.; Coelho, A.P.V.; Trelles, K.B.; Signor, C.; Rubin, M.A.; Oliveira, J.S.; Dornelles, G.L.; de Andrade, C.M.; et al. Neuroprotective effects of pretreatment with quercetin as assessed by acetylcholinesterase assay and behavioral testing in poloxamer-407 induced hyperlipidemic rats. Biomed. Pharmacother. 2017, 88, 1054-1063. [CrossRef] [PubMed]

191. Adedara, I.A.; Ego, V.C.; Subair, T.I.; Oyediran, O.; Farombi, E.O. Quercetin Improves Neurobehavioral Performance Through Restoration of Brain Antioxidant Status and Acetylcholinesterase Activity in Manganese-Treated Rats. Neurochemical 2017, 42, 1219-1229. [CrossRef] [PubMed]

192. Baral, S.; Pariyar, R.; Kim, J.; Lee, H.-S.; Seo, J. Quercetin-3-O-glucuronide promotes the proliferation and migration of neural stem cells. Neurobiol. Aging 2017, 52, 39-52. [CrossRef] 
193. Mesram, N.; Nagapuri, K.; Banala, R.R.; Nalagoni, C.R.; Karnati, P.R. Quercetin treatment against NaF induced oxidative stress related neuronal and learning changes in developing rats quercetin treatment against neuronal and learning changes in rats. $J$. King Saud Univ. Sci. 2017, 29, 221-229. [CrossRef]

194. Mehta, V.; Parashar, A.; Sharma, A.; Singh, T.R.; Udayabanu, M. Quercetin ameliorates chronic unpredicted stress-mediated memory dysfunction in male Swiss albino mice by attenuating insulin resistance and elevating hippocampal GLUT4 levels independent of insulin receptor expression. Horm. Behav. 2017, 89, 13-22. [CrossRef] [PubMed]

195. Moghbelinejad, S.; Alizadeh, S.; Mohammadi, G.; Khodabandehloo, F.; Rashvand, Z.; Najafipour, R.; Nassiri-Asl, M. The effects of quercetin on the gene expression of the GABAA receptor $\alpha 5$ subunit gene in a mouse model of kainic acid-induced seizure. $J$. Physiol. Sci. 2017, 67, 339-343. [CrossRef]

196. Kim, M.S.; Seo, J.Y.; Oh, J.; Jang, Y.K.; Lee, C.H.; Kim, J.-S. Neuroprotective Effect of Halophyte Salicornia herbacea L. Is Mediated by Activation of Heme Oxygenase-1 in Mouse Hippocampal HT22 Cells. J. Med. Food 2017, 20, 140-151. [CrossRef]

197. Chen, B.H.; Park, J.H.; Ahn, J.H.; Cho, J.H.; Kim, I.H.; Lee, J.C.; Won, M.-H.; Lee, C.-H.; Hwang, I.K.; Kim, J.-D.; et al. Pretreated quercetin protects gerbil hippocampal CA1 pyramidal neurons from transient cerebral ischemic injury by increasing the expression of antioxidant enzymes. Neural Regen. Res. 2017, 12, 220-227.

198. Pattanashetti, L.A.; Taranalli, A.D.; Parvatrao, V.; Malabade, R.H.; Kumar, D. Evaluation of neuroprotective effect of quercetin with donepezil in scopolamine-induced amnesia in rats. Indian J. Pharmacol. 2017, 49, 60-64. [PubMed]

199. Ola, M.S.; Ahmed, M.M.; Shams, S.; Al-Rejaie, S.S. Neuroprotective effects of quercetin in diabetic rat retina. Saudi J. Biol. Sci. 2017, 24, 1186-1194. [CrossRef]

200. de Souza, S.R.G.; Neto, M.H.M.; Perles, J.V.C.M.; Frez, F.C.V.; Zignani, I.; Ramalho, F.V.; Hermes-Uliana, C.; Bossolani, G.D.P.; Zanoni, J.N. Antioxidant effects of the quercetin in the jejunal myenteric innervation of diabetic rats. Front. Med. 2017, 4, 8. [CrossRef]

201. Hajizadeh Moghaddam, A.; Zare, M.; Rostamian, S.; Khanjani, S. The protective effect of quercetin and it nanocrystal on anxiety-like behaviors induced by animal model of Alzheimer's disease. J. Med. Plant Res. 2017, 16, 158-168.

202. Li, J.; Yuan, B.; Wei, C.; Gao, J. Neuroprotective and neurorescue effects of eggplant extract in 6-OHDA-induced Parkinson's rat model. Biomed. Res. J. 2017, 28, 7220-7229.

203. Singh, V.; Kahol, A.; Singh, I.P.; Saraf, I.; Shri, R. Evaluation of anti-amnesic effect of extracts of selected Ocimum species using in-vitro and in-vivo models. J. Ethnopharmacol. 2016, 193, 490-499. [CrossRef] [PubMed]

204. Maciel, R.M.; Carvalho, F.B.; Olabiyi, A.A.; Schmatz, R.; Gutierres, J.M.; Stefanello, N.; Zanini, D.; Rosa, M.M.; Andrade, C.M.; Rubin, M.A.; et al. Neuroprotective effects of quercetin on memory and anxiogenic-like behavior in diabetic rats: Role of ectonucleotidases and acetylcholinesterase activities. Biomed. Pharmacother. 2016, 84, 559-568. [CrossRef] [PubMed]

205. Martín-Aragón, S.; Jiménez-Aliaga, K.L.; Benedí, J.; Bermejo-Bescós, P. Neurohormetic responses of quercetin and rutin in a cell line over-expressing the amyloid precursor protein (APPswe cells). Phytomedicine 2016, 23, 1285-1294. [CrossRef]

206. Pogačnik, L.; Pirc, K.; Palmela, I.; Skrt, M.; Kwang, K.S.; Brites, D.; Brito, M.A.; Ulrih, N.P.; Silva, R.F.M. Potential for brain accessibility and analysis of stability of selected flavonoids in relation to neuroprotection in vitro. Brain Res. 2016, 1651, 17-26. [CrossRef]

207. Kim, M.-S.; Bang, J.H.; Lee, J.; Han, J.-S.; Baik, T.G.; Jeon, W.K. Ginkgo biloba L. extract protects against chronic cerebral hypoperfusion by modulating neuroinflammation and the cholinergic system. Phytomedicine 2016, 23, 1356-1364. [CrossRef]

208. Du, G.; Zhao, Z.; Chen, Y.; Li, Z.; Tian, Y.; Liu, Z.; Liu, B.; Song, J. Quercetin attenuates neuronal autophagy and apoptosis in rat traumatic brain injury model via activation of PI3K/Akt signaling pathway. Neurol. Res. 2016, 38, 1012-1019. [CrossRef]

209. Park, E.; Chun, H.S. Protective effects of Quercetin on dieldrin-induced endoplasmic reticulum stress and apoptosis in dopaminergic neuronal cells. NeuroReport 2016, 27, 1140-1146. [CrossRef]

210. Lee, M.; McGeer, E.G.; McGeer, P.L. Quercetin, not caffeine, is a major neuroprotective component in coffee. Neurobiol. Aging 2016, 46, 113-123. [CrossRef]

211. Pei, B.; Yang, M.; Qi, X.; Shen, X.; Chen, X.; Zhang, F. Quercetin ameliorates ischemia/reperfusion-induced cognitive deficits by inhibiting ASK1/JNK3/caspase-3 by enhancing the Akt signaling pathway. Biochem. Biophys. Res. Commun. 2016, 478, 199-205. [CrossRef] [PubMed]

212. Zargar, S.; Siddiqi, N.J.; Ansar, S.; Alsulaimani, M.S.; El Ansary, A.K. Therapeutic role of quercetin on oxidative damage induced by acrylamide in rat brain. Pharm. Biol. 2016, 54, 1763-1767. [CrossRef] [PubMed]

213. Pandey, A.K.; Shukla, S.C.; Bhattacharya, P.; Patnaik, R. A possible therapeutic potential of quercetin through inhibition of $\mu$-calpain in hypoxia induced neuronal injury: A molecular dynamics simulation study. Neural Regen. Res. 2016, 11, 1247-1253. [CrossRef]

214. El-Horany, H.E.; El-Latif, R.N.A.; ElBatsh, M.M.; Emam, M.N. Ameliorative Effect of Quercetin on Neurochemical and Behavioral Deficits in Rotenone Rat Model of Parkinson's Disease: Modulating Autophagy (Quercetin on Experimental Parkinson's Disease). J. Biochem. Mol. Toxicol. 2016, 30, 360-369. [CrossRef] [PubMed]

215. Lee, Y.-J.; Bernstock, J.D.; Nagaraja, N.; Ko, B.; Hallenbeck, J.M. Global SUMOylation facilitates the multimodal neuroprotection afforded by quercetin against the deleterious effects of oxygen/glucose deprivation and the restoration of oxygen/glucose. J. Neurochem. 2016, 138, 101-116. [CrossRef]

216. Sharma, D.R.; Wani, W.Y.; Sunkaria, A.; Kandimalla, R.J.; Sharma, R.K.; Verma, D.; Bal, A.; Gill, K.D. Quercetin attenuates neuronal death against aluminum-induced neurodegeneration in the rat hippocampus. Neuroscience 2016, 324, 163-176. [CrossRef] 
217. Moghbelinejad, S.; Rashvand, Z.; Khodabandehloo, F.; Mo, G.; Nassiri-Asl, M. Modulation of the expression of the GABAa receptor $\beta 1$ and $\beta 3$ subunits by pretreatment with Quercetin in the ka model of epilepsy in mice-The effect of Quercetin on GABAA receptor beta subunits. J. Pharmacopunct. 2016, 19, 163-166.

218. Oboh, G.; Nwanna, E.E.; Oyeleye, S.I.; Olasehinde, T.A.; Ogunsuyi, O.B.; Boligon, A.A. In vitro neuroprotective potentials of aqueous and methanol extracts from Heinsia crinita leaves. Food Sci. Hum. Wellness 2016, 5, 95-102. [CrossRef]

219. Wu, Y.; Sun, J.; George, J.; Ye, H.; Cui, Z.; Li, Z.; Liu, Q.; Zhang, Y.; Ge, D.; Liu, Y. Study of neuroprotective function of Ginkgo biloba extract (EGb761) derived-flavonoid monomers using a three-dimensional stem cell-derived neural model. Biotechnol. Prog. 2016, 32, 735-744. [CrossRef] [PubMed]

220. Surapaneni, S.; Prakash, T.; Ansari, M.; Manjunath, P.M.; Kotresha, D.; Goli, D. Study on cerebroprotective actions of Clerodendron glandulosumleaves extract against long term bilateral common carotid artery occlusion in rats. Biomed. Pharmacother. 2016, 80, 87-94. [CrossRef] [PubMed]

221. Jiang, W.; Luo, T.; Li, S.; Zhou, Y.; Shen, X.-Y.; He, F.; Xu, J.; Wang, H.-Q. Quercetin protects against Okadaic acid-induced injury via MAPK and PI3K/Akt/GSK3 $\beta$ signaling pathways in HT22 hippocampal neurons. PLoS ONE 2016, 11, e0152371.

222. Waseem, M.; Parvez, S. Neuroprotective activities of curcumin and quercetin with potential relevance to mitochondrial dysfunction induced by oxaliplatin. Protoplasma 2016, 253, 417-430. [CrossRef] [PubMed]

223. Kanter, M.; Unsal, C.; Aktas, C.; Erboga, M. Neuroprotective effect of quercetin against oxidative damage and neuronal apoptosis caused by cadmium in hippocampus. Toxicol. Ind. Health 2016, 32, 541-550. [CrossRef] [PubMed]

224. Mu, X.; Yuan, X.; Du, L.-D.; He, G.-R.; Du, G.-H. Antagonism of quercetin against tremor induced by unilateral striatal lesion of 6-OHDA in rats. J. Asian Nat. Prod. Res. 2016, 18, 65-71. [CrossRef] [PubMed]

225. Chen, L.; Sun, L.; Liu, Z.; Wang, H.; Xu, C. Protection afforded by quercetin against $\mathrm{H}_{2} \mathrm{O}_{2}$-induced apoptosis on PC12 cells via activating PI3K/Akt signal pathway. J. Recept. Signal Transduct. 2016, 36, 98-102. [CrossRef]

226. Zabenko, Y.Y.; Pivneva, T.A. Flavonoid quercetin reduces gliosis after repetitive mild traumatic brain injury in mice. Fiziolohichnyı Zhurnal 2016, 62, 50-56. [CrossRef]

227. Kong, Y.; Li, K.; Fu, T.; Wan, C.; Zhang, D.; Song, H.; Zhang, Y.; Liu, N.; Gan, Z.; Yuan, L. Quercetin ameliorates A $\beta$ toxicity in Drosophila AD model by modulating cell cycle-related protein expression. Oncotarget 2016, 7, 67716-67731. [CrossRef]

228. Lee, B.K.; Jung, Y.-S. Allium cepa Extract and quercetin Protect Neuronal Cells from Oxidative Stress via PKC- $\epsilon$ Inactivation/ERK1/2 Activation. Oxid. Med. Cell. Longev. 2016, 2016, 2495624. [CrossRef]

229. Kumar, A.; Bora, K.S.; Jaggi, A.S.; Shri, R. Comparative evaluation of neuroprotective effect of three varieties of Allium cepa in chronic constriction injury induced neuropathic pain. Thai J. Pharm. Sci. 2016, 40, 9-20.

230. Ma, J.-Q.; Luo, R.-Z.; Jiang, H.-X.; Liu, C.-M. Quercitrin offers protection against brain injury in mice by inhibiting oxidative stress and inflammation. Food Funct. 2016, 7, 549-556. [CrossRef]

231. Nichols, M.; Zhang, J.; Polster, B.M.; Elustondo, P.A.; Thirumaran, A.; Pavlov, E.V.; Robertson, G.S. Synergistic neuroprotection by epicatechin and quercetin: Activation of convergent mitochondrial signaling pathways. Neuroscience 2015, 308, 75-94. [CrossRef]

232. Moniruzzaman, M.; Asaduzzaman, M.; Hossain, M.S.; Sarker, J.; Rahman, S.M.A.; Rashid, M.; Rahman, M.M. In vitro antioxidant and cholinesterase inhibitory activities of methanolic fruit extract of Phyllanthus acidus. BMC Compl. Altern. Med. 2015, 15, 1. [CrossRef] [PubMed]

233. Mrvová, N.; Škandík, M.; Kuniaková, M.; Račková, L. Modulation of BV-2 microglia functions by novel quercetin pivaloyl ester. Neurochem. Int. 2015, 90, 246-254. [CrossRef]

234. Chakraborty, J.; Rajamma, U.; Jana, N.; Mohanakumar, K.P. Quercetin improves the activity of the ubiquitin-proteasomal system in 150Q mutated huntingtin-expressing cells but exerts detrimental effects on neuronal survivability. J. Neurosci. Res. 2015, 93, 1581-1591. [CrossRef] [PubMed]

235. Blasina, F.; Vaamonde, L.; Silvera, F.; Tedesco, A.C.; Dajas, F. Intravenous nanosomes of quercetin improve brain function and hemodynamic instability after severe hypoxia in newborn piglets. Neurochem. Int. 2015, 89, 149-156. [CrossRef] [PubMed]

236. García-Morales, G.; Huerta-Reyes, M.; González-Cortazar, M.; Zamilpa, A.; Jiménez-Ferrer, E.; Silva-García, R.; Román-Ramos, R.; Aguilar-Rojas, A. Anti-inflammatory, antioxidant and anti-acetylcholinesterase activities of Bouvardia ternifolia: Potential implications in Alzheimer's disease. Arch. Pharm. Res. 2015, 38, 1369-1379. [CrossRef] [PubMed]

237. Denny Joseph, K.M. Muralidhara Combined Oral Supplementation of Fish Oil and quercetin Enhances Neuroprotection in a Chronic Rotenone Rat Model: Relevance to Parkinson's Disease. Neurochem. Res. 2015, 40, 894-905. [CrossRef]

238. Magalingam, K.B.; Radhakrishnan, A.; Ramdas, P.; Haleagrahara, N. Quercetin Glycosides Induced Neuroprotection by Changes in the Gene Expression in a Cellular Model of Parkinson's Disease. J. Mol. Neurosci. 2015, 55, 609-617. [CrossRef] [PubMed]

239. Lei, X.; Chao, H.; Zhang, Z.; Lv, J.; Li, S.; Wei, H.; Xue, R.; Li, F.; Li, Z. Neuroprotective effects of quercetin in a mouse model of brain ischemic/reperfusion injury via anti-apoptotic mechanisms based on the Akt pathway. Mol. Med. Rep. 2015, 12, 3688-3696. [CrossRef]

240. Ahn, T.-B.; Jeon, B.S. The role of quercetin on the survival of neuron-like PC12 cells and the expression of $\alpha$-synuclein. Neural Regen. Res. 2015, 10, 1113-1119.

241. Xia, S.-F.; Xie, Z.-X.; Qiao, Y.; Li, L.-R.; Cheng, X.-R.; Tang, X.; Shi, Y.-H.; Le, G.-W. Differential effects of quercetin on hippocampusdependent learning and memory in mice fed with different diets related with oxidative stress. Physiol. Behav. 2015, 138, 325-331. [CrossRef] 
242. Unsal, C.; Kanter, M.; Aktas, C.; Erboga, M. Role of quercetin in cadmium-induced oxidative stress, neuronal damage, and apoptosis in rats. Toxicol. Ind. Health 2015, 31, 1106-1115. [CrossRef]

243. Li, Y.; Zhou, S.; Li, J.; Sun, Y.; Hasimu, H.; Liu, R.; Zhang, T. Quercetin protects human brain microvascular endothelial cells from fibrillar $\beta$-amyloid1-40-induced toxicity. Acta Pharm. Sin. B. 2015, 5, 47-54. [CrossRef] [PubMed]

244. Ashrafpour, M.; Parsaei, S.; Sepehri, H. Quercetin improved spatial memory dysfunctions in rat model of intracerebroventricular streptozotocin-induced sporadic Alzheimer'sdisease. Natl. J. Physiol. Pharm. Pharmacol. 2015, 5, 411-415. [CrossRef]

245. Sabogal-Guáqueta, A.M.; Muñoz-Manco, J.I.; Ramírez-Pineda, J.R.; Lamprea-Rodriguez, M.; Osorio, E.; Cardona-Gómez, G.P. The flavonoid quercetin ameliorates Alzheimer's disease pathology and protects cognitive and emotional function in aged triple transgenic Alzheimer's disease model mice. Neuropharmacology 2015, 93, 134-145. [CrossRef]

246. Roshanzamir, F.; Yazdanparast, R. Quercetin attenuates cell apoptosis of oxidant-stressed SK-N-MC cells while suppressing up-regulation of the defensive element, HIF-1 $\alpha$. Neuroscience 2014, 277, 780-793. [CrossRef]

247. Abdalla, F.H.; Schmatz, R.; Cardoso, A.M.; Carvalho, F.B.; Baldissarelli, J.; de Oliveira, J.S.; Rosa, M.M.; Gonçalves Nunes, M.A.; Rubin, M.A.; da Cruz, I.B.M.; et al. Quercetin protects the impairment of memory and anxiogenic-like behavior in rats exposed to cadmium: Possible involvement of the acetylcholinesterase and $\mathrm{Na}^{+}, \mathrm{K}^{+}$-ATPase activities. Physiol. Behav. 2014, 135, 152-167. [CrossRef] [PubMed]

248. Beckmann, D.V.; Carvalho, F.B.; Mazzanti, C.M.; Dos Santos, R.P.; Andrades, A.O.; Aiello, G.; Rippilinger, A.; Graça, D.L.; Abdalla, F.H.; Oliveira, L.S.; et al. Neuroprotective role of quercetin in locomotor activities and cholinergic neurotransmission in rats experimentally demyelinated with ethidium bromide. Life Sci. 2014, 103, 79-87. [CrossRef]

249. Kumar, P.; Choonara, Y.E.; Modi, G.; Naidoo, D.; Pillay, V. Cur(Que)min: A neuroactive permutation of Curcumin and Quercetin for treating spinal cord injury. Med. Hypotheses 2014, 82, 437-441. [CrossRef] [PubMed]

250. Qu, X.; Qi, D.; Dong, F.; Wang, B.; Guo, R.; Luo, M.; Yao, R. Quercetin improves hypoxia-ischemia induced cognitive deficits via promoting remyelination in neonatal rat. Brain Res. 2014, 1553, 31-40. [CrossRef] [PubMed]

251. Dong, Y.-S.; Wang, J.-L.; Feng, D.-Y.; Qin, H.-Z.; Wen, H.; Yin, Z.-M.; Gao, G.-D.; Li, C. Protective effect of quercetin against oxidative stress and brain edema in an experimental rat model of subarachnoid haemorrhage. Int. J. Med. Sci. 2014, 11, 282-290. [CrossRef] [PubMed]

252. Chang, H.-C.; Yang, Y.-R.; Wang, P.S.; Wang, R.-Y. Quercetin enhances exercise-mediated neuroprotective effects in brain ischemic rats. Med. Sci. Sports Exerc. 2014, 46, 1908-1916. [CrossRef]

253. Kumar, B.; Gupta, S.K.; Nag, T.C.; Srivastava, S.; Saxena, R.; Jha, K.A.; Srinivasan, B.P. Retinal neuroprotective effects of quercetin in streptozotocin-induced diabetic rats. Exp. Eye Res. 2014, 125, 193-202. [CrossRef] [PubMed]

254. Yang, T.; Kong, B.; Gu, J.-W.; Kuang, Y.-Q.; Cheng, L.; Yang, W.-T.; Xia, X.; Shu, H.-F. Anti-apoptotic and anti-oxidative roles of quercetin after traumatic brain injury. Cell. Mol. Neurobiol. 2014, 34, 797-804. [CrossRef] [PubMed]

255. Qu, L.; Liang, X.C.; Gu, B.; Liu, W. Quercetin alleviates high glucose-induced Schwann cell damage by autophagy. Neural Regen. Res. 2014, 9, 1195-1203. [CrossRef] [PubMed]

256. Zhang, T.-T.; Lu, C.-L.; Jiang, J.-G. Bioactivity evaluation of ingredients identified from the fruits of Amomum tsaoko Crevost et Lemaire, a Chinese spice. Food Funct. 2014, 5, 1747-1754. [CrossRef]

257. Mathew, M.; Subramanian, S. In vitro evaluation of anti-Alzheimer effects of dry ginger (Zingiber officinale Roscoe) extract. Indian J. Exp. Biol. 2014, 52, 606-612. [PubMed]

258. Rinwa, P.; Kumar, A. Quercetin suppress microglial neuroinflammatory response and induce antidepressent-like effect in olfactory bulbectomized rats. Neuroscience 2013, 255, 86-98. [CrossRef] [PubMed]

259. Prasad, J.; Baitharu, I.; Sharma, A.K.; Dutta, R.; Prasad, D.; Singh, S.B. Quercetin reverses hypobaric hypoxia-induced hippocampal neurodegeneration and improves memory function in the rat. High Alt. Med. Biol. 2013, 14, 383-394. [CrossRef]

260. Ferreira, P.E.B.; Lopes, C.R.P.; Alves, A.M.P.; Alves, É.P.B.; Linden, D.R.; Zanoni, J.N.; Buttow, N.C. Diabetic neuropathy: An evaluation of the use of quercetin in the cecum of rats. World J. Gastroenterol. 2013, 19, 6416-6426. [CrossRef]

261. Pandey, A.K.; Bhattacharya, P.; Shukla, S.C.; Paul, S.; Patnaik, R. Neuroprotective effects of Quercetin in chemical hypoxia: In silico evaluation of the hypothesis exploring PKC inhibition-mediated pharmacotherapy. Med. Chem. Res. 2013, 22, $4836-4841$. [CrossRef]

262. Lu, C.-W.; Lin, T.-Y.; Wang, S.-J. Quercetin inhibits depolarization-evoked glutamate release in nerve terminals from rat cerebral cortex. NeuroToxicology 2013, 39, 1-9. [CrossRef]

263. Selvakumar, K.; Bavithra, S.; Ganesh, L.; Krishnamoorthy, G.; Venkataraman, P.; Arunakaran, J. Polychlorinated biphenyls induced oxidative stress mediated neurodegeneration in hippocampus and behavioral changes of adult rats: Anxiolytic-like effects of quercetin. Toxicol. Lett. 2013, 222, 45-54. [CrossRef]

264. Abdalla, F.H.; Cardoso, A.M.; Pereira, L.B.; Schmatz, R.; Gonçalves, J.F.; Stefanello, N.; Fiorenza, A.M.; Gutierres, J.M.; Da Silva Serres, J.D.; Zanini, D.; et al. Neuroprotective effect of quercetin in ectoenzymes and acetylcholinesterase activities in cerebral cortex synaptosomes of cadmium-exposed rats. Mol. Cell Biochem. 2013, 381, 1-8. [CrossRef]

265. Costa, L.G.; Tait, L.; De Laat, R.; Dao, K.; Giordano, G.; Pellacani, C.; Cole, T.B.; Furlong, C.E. Modulation of paraoxonase 2 (PON2) in mouse brain by the polyphenol quercetin: A mechanism of neuroprotection? Neurochem. Res. 2013, 38, 1809-1818. [CrossRef] [PubMed] 
266. Shi, Y.; Liang, X.-C.; Zhang, H.; Wu, Q.-L.; Qu, L.; Sun, Q. Quercetin protects rat dorsal root ganglion neurons against high glucose-induced injury in vitro through Nrf-2/HO-1 activation and NF-kB inhibition. Acta Pharmacol. Sin. 2013, 34, 1140-1148. [CrossRef] [PubMed]

267. Gómez del Rio, M.A.; Sánchez-Reus, M.I.; Iglesias, I.; Pozo, M.A.; García-Arencibia, M.; Fernández-Ruiz, J.; García-García, L.; Delgado, M.; Benedí, J. Neuroprotective properties of standardized extracts of hypericum perforatum on rotenone model of parkinson's disease. CNS Neurol. Disord. Drug Targets 2013, 12, 665-679. [CrossRef]

268. Tangsaengvit, N.; Kitphati, W.; Tadtong, S.; Bunyapraphatsara, N.; Nukoolkarn, V. Neurite outgrowth and neuroprotective effects of quercetin from caesalpinia mimosoides lamk. on CULTURED P19-derived neurons. Evid. Based Compl. Altern. Med. 2013, 2013, 838051. [CrossRef]

269. Selvakumar, K.; Prabha, R.L.; Saranya, K.; Bavithra, S.; Krishnamoorthy, G.; Arunakaran, J. Polychlorinated biphenyls impair blood-brain barrier integrity via disruption of tight junction proteins in cerebrum, cerebellum and hippocampus of female Wistar rats: Neuropotential role of quercetin. Hum. Exp. Toxicol. 2013, 32, 706-720. [CrossRef] [PubMed]

270. Annapurna, A.; Ansari, M.A.; Manjunath, P.M. Partial role of multiple pathways in infarct size limiting effect of quercetin and rutin against cerebral ischemia-reperfusion injury in rats. Eur. Rev. Med. Pharmacol. Sci. 2013, 17, 491-500. [PubMed]

271. Sharma, D.R.; Wani, W.Y.; Sunkaria, A.; Kandimalla, R.J.L.; Verma, D.; Cameotra, S.S.; Gill, K.D. Quercetin protects against chronic aluminum-induced oxidative stress and ensuing biochemical, cholinergic, and neurobehavioral impairments in rats. Neurotox. Res. 2013, 23, 336-357. [CrossRef]

272. Karuppagounder, S.S.; Madathil, S.K.; Pandey, M.; Haobam, R.; Rajamma, U.; Mohanakumar, K.P. Quercetin up-regulates mitochondrial complex-I activity to protect against programmed cell death in rotenone model of Parkinson's disease in rats. Neuroscience 2013, 236, 136-148. [CrossRef]

273. Liu, R.; Zhang, T.-T.; Zhou, D.; Bai, X.-Y.; Zhou, W.-L.; Huang, C.; Song, J.-K.; Meng, F.-R.; Wu, C.-X.; Li, L.; et al. Quercetin protects against the A $\beta 25-35$-induced amnesic injury: Involvement of inactivation of RAGE-mediated pathway and conservation of the NVU. Neuropharmacology 2013, 67, 419-431. [CrossRef]

274. Haleagrahara, N.; Siew, C.J.; Ponnusamy, K. Effect of quercetin and desferrioxamine on 6-hydroxydopamine (6-OHDA) induced neurotoxicity in striatum of rats. J. Toxicol. Sci. 2013, 38, 25-33. [CrossRef] [PubMed]

275. Denny Joseph, K.M. Muralidhara Enhanced neuroprotective effect of fish oil in combination with quercetin against 3nitropropionic acid induced oxidative stress in rat brain. Prog. Neuropsychopharmacol. Biol. Psychiatry 2013, 40, 83-92. [CrossRef]

276. Yang, E.-J.; Kim, G.-S.; Kim, J.; Song, K.-S. Protective effects of onion-derived quercetin on glutamate-mediated hippocampal neuronal cell death. Pharmacogn. Mag. 2013, 9, 302-308. [CrossRef]

277. Dal Belo, C.A.; Lucho, A.P.D.B.; Vinadé, L.; Rocha, L.; Seibert França, H.; Marangoni, S.; Rodrigues-Simioni, L. In vitro antiophidian mechanisms of Hypericum brasiliense choisy standardized extract: Quercetin-dependent neuroprotection. BioMed Res. Int. 2013, 2013, 943520. [CrossRef] [PubMed]

278. Selvakumar, K.; Bavithra, S.; Krishnamoorthy, G.; Ganesh, A.; Venkataraman, P.; Arunakaran, J. Impact of quercetin on PCBs (Aroclor-1254)-induced impairment of dopaminergic receptors expression in hippocampus of adult male Wistar rats. Biomed. Prev. Nutr. 2013, 3, 42-52. [CrossRef]

279. Keddy, P.G.W.; Dunlop, K.; Warford, J.; Samson, M.L.; Jones, Q.R.D.; Rupasinghe, H.P.V.; Robertson, G.S. Neuroprotective and Anti-Inflammatory Effects of the Flavonoid-Enriched Fraction AF4 in a Mouse Model of Hypoxic-Ischemic Brain Injury. PLoS ONE 2012, 7, 12. [CrossRef]

280. Lopes, C.R.P.; Ferreira, P.E.B.; Zanoni, J.N.; Alves, A.M.P.; Alves, É.P.B.; Buttow, N.C. Neuroprotective effect of quercetin on the duodenum enteric nervous system of streptozotocin-induced diabetic rats. Dig. Dis. Sci. 2012, 57, 3106-3115. [CrossRef] [PubMed]

281. Raygude, K.S.; Kandhare, A.D.; Ghosh, P.; Ghule, A.E.; Bodhankar, S.L. Evaluation of ameliorative effect of quercetin in experimental model of alcoholic neuropathy in rats. Inflammopharmacology 2012, 20, 331-341. [CrossRef] [PubMed]

282. Yao, R.-Q.; Qi, D.-S.; Yu, H.-L.; Liu, J.; Yang, L.-H.; Wu, X.-X. Quercetin attenuates cell apoptosis in focal cerebral ischemia rat brain via activation of BDNF-TrkB-PI3K/Akt signaling pathway. Neurochem. Res. 2012, 37, 2777-2786. [CrossRef] [PubMed]

283. Nabavi, S.F.; Nabavi, S.M.; Latifi, A.M.; Mirzaei, M.; Habtemariam, S.; Moghaddam, A.H. Mitigating role of quercetin against sodium fluoride-induced oxidative stress in the rat brain. Pharm. Biol. 2012, 50, 1380-1383. [CrossRef] [PubMed]

284. Sarkar, A.; Angeline, M.S.; Anand, K.; Ambasta, R.K.; Kumar, P. Naringenin and Quercetin reverse the effect of hypobaric hypoxia and elicit neuroprotective response in the murine model. Brain Res. 2012, 1481, 59-70. [CrossRef]

285. Kandhare, A.D.; Raygude, K.S.; Shiva Kumar, V.; Rajmane, A.R.; Visnagri, A.; Ghule, A.E.; Ghosh, P.; Badole, S.L.; Bodhankar, S.L. Ameliorative effects quercetin against impaired motor nerve function, inflammatory mediators and apoptosis in neonatal streptozotocin-induced diabetic neuropathy in rats. Biomed. Aging Pathol. 2012, 2, 173-186. [CrossRef]

286. Park, J.H.; Jung, J.W.; Ahn, Y.-J.; Kwon, H.W. Neuroprotective properties of phytochemicals against paraquat-induced oxidative stress and neurotoxicity in Drosophila melanogaster. Pestic. Biochem. Physiol. 2012, 104, 118-125. [CrossRef]

287. Mansoorali, K.P.; Prakash, T.; Kotresha, D.; Prabhu, K.; Rama Rao, N. Cerebroprotective effect of Eclipta alba against global model of cerebral ischemia induced oxidative stress in rats. Phytomedicine 2012, 19, 1108-1116. [CrossRef] 
288. Bournival, J.; Plouffe, M.; Renaud, J.; Provencher, C.; Martinoli, M.-G. Quercetin and sesamin protect dopaminergic cells from $\mathrm{MPP}^{+}$-induced neuroinflammation in a microglial (N9)-neuronal (PC12) coculture system. Oxid. Med. Cell. Longev. 2012, 2012, 921941. [CrossRef] [PubMed]

289. Pandey, A.K.; Verma, S.; Bhattacharya, P.; Paul, S.; Mishra, A.; Patnaik, R. An in-silico strategy to explore neuroprotection by quercetin in cerebral ischemia: A novel hypothesis based on inhibition of matrix metalloproteinase (MMPs) and acid sensing ion channel 1a (ASIC1a). Med. Hypotheses 2012, 79, 76-81. [CrossRef]

290. Jazvinšćak Jembrek, M.; Vuković, L.; Puhović, J.; Erhardt, J.; Oršolić, N. Neuroprotective effect of quercetin against hydrogen peroxide-induced oxidative injury in P19 neurons. J. Mol. Neurosci. 2012, 47, 286-299. [CrossRef]

291. Yang, E.-J.; Kim, S.-I.; Park, S.-Y.; Bang, H.-Y.; Jeong, J.H.; So, J.-H.; Rhee, I.-K.; Song, K.-S. Fermentation enhances the in vitro antioxidative effect of onion (Allium cepa) via an increase in quercetin content. Food Chem. Toxicol. 2012, 50, 2042-2048. [CrossRef] [PubMed]

292. Cho, N.; Choi, J.H.; Yang, H.; Jeong, E.J.; Lee, K.Y.; Kim, Y.C.; Sung, S.H. Neuroprotective and anti-inflammatory effects of flavonoids isolated from Rhus verniciflua in neuronal HT22 and microglial BV2 cell lines. Food Chem. Toxicol. 2012, 50, 1940-1945. [CrossRef] [PubMed]

293. Selvakumar, K.; Bavithra, S.; Suganthi, M.; Benson, C.S.; Elumalai, P.; Arunkumar, R.; Krishnamoorthy, G.; Venkataraman, P.; Arunakaran, J. Protective role of quercetin on PCBs-induced oxidative stress and apoptosis in hippocampus of adult rats. Neurochem. Res. 2012, 37, 708-721. [CrossRef] [PubMed]

294. Prakash, R.; Jayashree, V.; Pranavswarup, G. Neuroprotective effect of flavonoids in global cerebral ischemic conditions. Res. J. Pharm. Biol. Chem. Sci. 2012, 3, 1161-1176.

295. Selvakumar, K.; Bavithra, S.; Krishnamoorthy, G.; Venkataraman, P.; Arunakaran, J. Polychlorinated biphenyls-induced oxidative stress on rat hippocampus: A neuroprotective role of quercetin. Sci. World J. 2012, 2012, 980314. [CrossRef] [PubMed]

296. Bavithra, S.; Selvakumar, K.; Pratheepa Kumari, R.; Krishnamoorthy, G.; Venkataraman, P.; Arunakaran, J. Polychlorinated Biphenyl (PCBs)-induced oxidative stress plays a critical role on cerebellar dopaminergic receptor expression: Ameliorative role of quercetin. Neurotox. Res. 2012, 21, 149-159. [CrossRef] [PubMed]

297. Barreira, J.C.M.; Arraibi, A.A.; Ferreira, I.C.F.R. Bioactive and functional compounds in apple pomace from juice and cider manufacturing: Potential use in dermal formulations. Trends Food Sci. Technol. 2019, 90, 76-87. [CrossRef]

298. Diñeiro García, Y.; Valles, B.S.; Picinelli Lobo, A. Phenolic and antioxidant composition of by-products from the cider industry: Apple pomace. Food Chem. 2009, 117, 731-738. [CrossRef]

299. Sójka, M.; Kołodziejczyk, K.; Milala, J.; Abadias, M.; Viñas, I.; Guyot, S.; Baron, A. Composition and properties of the polyphenolic extracts obtained from industrial plum pomaces. J. Funct. Foods 2015, 12, 168-178. [CrossRef]

300. Marina, Z.; Noriham, A. Quantification of total phenolic compound and in vitro antioxidant potential of fruit peel extracts. Int. Food Res. J. 2014, 21, 1925-1929.

301. Vu, H.T.; Scarlett, C.J.; Vuong, Q.V. Phenolic compounds within banana peel and their potential uses: A review. J. Funct. Foods 2018, 40, 238-248. [CrossRef]

302. Wang, Y.C.; Chuang, Y.C.; Hsu, H.W. The flavonoid, carotenoid and pectin content in peels of citrus cultivated in Taiwan. Food Chem. 2008, 106, 277-284. [CrossRef]

303. Zeyada, N.N.; Zeitoum, M.A.M.; Barbary, O.M. Utilization of some vegetables and fruit waste as natural antioxidants. Alex. J. Food Sci. Technol. 2008, 5, 1-11.

304. Benítez, V.; Mollá, E.; Martín-Cabrejas, M.A.; Aguilera, Y.; López-Andréu, F.J.; Cools, K.; Terry, L.A.; Esteban, R.M. Characterization of industrial onion wastes (Allium cepa L.): Dietary fibre and bioactive compounds. Plant Foods Hum. Nutr. 2011, 66, 48-57. [CrossRef] [PubMed]

305. Lee, K.A.; Kim, K.T.; Kim, H.J.; Chung, M.S.; Chang, P.S.; Park, H.; Pai, H.D. Antioxidant activities of onion (Allium cepa L.) peel extracts produced by ethanol, hot water and subcritical water extraction. Food Sci. Biotechnol. 2014, 23, 615-621. [CrossRef]

306. Marrelli, M.; Amodeo, V.; Statti, G.; Conforti, F. Biological properties and bioactive components of L.: Focus on potential benefits in the treatment of obesity and related comorbidities. Molecules 2019, 24, 119. [CrossRef] [PubMed]

307. Sharma, K.; Mahato, N.; Lee, Y.R. Extraction, characterization and biological activity of citrus flavonoids. Rev. Chem. Eng. 2019, 35, 265-284. [CrossRef]

308. Farías-Campomanes, A.M.; A Meireles, M.A. Pisco bagasse as a potential source of bioactive compounds-A review. Recent Pat. Eng. 2013, 7, 41-50. [CrossRef]

309. Clifton, P.M. Effect of grape seed extract and quercetin on cardiovascular and endothelial parameters in high-risk subjects. J. Biomed. Biotechnol. 2004, 2004, 272-278. [CrossRef] [PubMed]

310. Castro-Vargas, H.I.; Baumann, W.; Ferreira, S.R.; Parada-Alfonso, F. Valorization of papaya (Carica papaya L.) agroindustrial waste through the recovery of phenolic antioxidants by supercritical fluid extraction. J. Food Sci. Technol. 2019, 56, 3055-3066. [CrossRef]

311. Yang, H.; Protiva, P.; Cui, B.; Ma, C.; Baggett, S.; Hequet, V.; Mori, S.; Weinstein, I.B.; Kennelly, E.J. New bioactive polyphenols from Theobroma grandiflorum ("cupuaçu"). J. Nat. Prod. 2003, 66, 1501-1504. [CrossRef]

312. Ballesteros-Vivas, D.; Álvarez-Rivera, G.; Morantes, S.J.; Sánchez-Camargo, A.P.; Ibáñez, E.; Parada-Alfonso, F.; Cifuentes, A. An integrated approach for the valorization of mango seed kernel: Efficient extraction solvent selection, phytochemical profiling and antiproliferative activity assessment. Food Res. Int. 2019, 126, 108616. [CrossRef] 
313. Yang, L.; Li, X.-F.; Zhang, Y.-O.; Cai, G.-P. Suppressive effects of quercetin-3-O-(6"-feruloyl)- $\beta$-D-galactopyranoside on adipogenesis in 3T3-L1 preadipocytes through down-regulation of PPAR $\gamma$ and C/EBP $\alpha$ expression. Phytother. Res. 2012, 26, $438-444$. [CrossRef] [PubMed]

314. Teleszko, M.; Wojdyło, A. Comparison of phenolic compounds and antioxidant potential between selected edible fruits and their leaves. J. Funct. Foods 2015, 14, 736-746. [CrossRef]

315. Sagar, N.A.; Pareek, S.; Sharma, S.; Yahia, E.M.; Lobo, M.G. Fruit and vegetable waste: Bioactive compounds, their extraction, and possible utilization. Compr. Rev. Food Sci. Food Saf. 2018, 17, 512-531. [CrossRef] [PubMed]

316. Benzarti, S.; Hamdi, H.; Lahmayer, I.; Toumi, W.; Kerkeni, A.; Belkadhi, K.; Sebei, H. Total phenolic compounds and antioxidant potential of quince (Cydonia oblonga Miller) leaf methanol extract. Int. J. Innov. Appl. Stud. 2015, 13, 518.

317. Silva, P.; Ferreira, S.; Nunes, F.M. Elderberry (Sambucus nigra L.) by-products a source of anthocyanins and antioxidant polyphenols. Ind. Crop Prod. 2017, 95, 227-234. [CrossRef]

318. Thomas, M.; Badr, A.; Desjardins, Y.; Gosselin, A.; Angers, P. Characterization of industrial broccoli discards (Brassica oleracea var. italica) for their glucosinolate, polyphenol and flavonoid contents using UPLC MS/MS and spectrophotometric methods Food Chem. 2018, 245, 4-1211. [CrossRef]

319. Gonzales, G.B.; Raes, K.; Coelus, S.; Struijs, K.; Smagghe, G.; Van Camp, J. Ultra(high)-pressure liquid chromatography-ele trospray ionization-time-of-flight-ion mobility-high definition mass spectrometry for the rapid identification and structural characterization of flavonoid glycosides from cauliflower waste. J. Chromatogr. A 2014, 1323, 39-48. [CrossRef] [PubMed]

320. Huynh, N.T.; Smagghe, G.; Gonzales, G.B.; Camp, J.-V.; Raes, K. Enzyme-Assisted Extraction Enhancing the Phenolic Release from Cauliflower (Brassica oleracea L. var. botrytis) Outer Leaves. J. Agric. Food Chem. 2014, 62, 7468-7476. [CrossRef]

321. Zheng, R.; Su, S.; Zhou, H.; Yan, H.; Ye, J.; Zhao, Z.; You, L.; Fu, X. Antioxidant/antihyperglycemic activity of phenolics from sugarcane (Saccharum officinarum L.) bagasse and identification by UHPLC-HR TOFMS. Ind. Crops. Prod. 2017, 101, 104-114. [CrossRef]

322. Zhao, Y.; Chen, M.; Zhao, Z.; Yu, S. The antibiotic activity and mechanisms of sugarcane (Saccharum officinarum L.) bagasse extract against food-borne pathogens. Food Chem. 2015, 185, 112-118. [CrossRef] [PubMed]

323. Marques, T.R.; Caetano, A.A.; Simão, A.A.; de O. Castro, F.C.; de Oliveira, R.V.; Corrêa, A.D. Methanolic extract of Malpighia emarginata bagasse: Phenolic Compounds and inhibitory potential on digestive enzymes. Braz. J. Pharmacog. 2016, 26, 191-196. [CrossRef]

324. Zhang, F.; Yang, Y.; Su, P.; Guo, Z. Microwave-assisted Extraction of Rutin and Quercetin from the Stalks of Euonymus alatus (Thunb.) Sieb. Phytochem. Anal. 2009, 20,33-37. [CrossRef]

325. Balaraman, H.B.; Sivasubramaniyam, A.; Rathnasamy, S.K. High selective purification of Quercetin from Peanut hull using protic deep eutectic mixture based liquid-liquid microextraction. Microchem. J. 2020, 152, 104444. [CrossRef]

326. Flórez-Montes, C.; Mosquera-Martínez, Ó.M.; Rojas-González, A.F. Prospective use of fruit byproducts in Colombia according to their antioxidant capacity [Uso prospectivo de subproductos de frutas en Colombia según su capacidad antioxidante]. Rev. Acad. Colomb. Cienc. Exact. Fis. Nat. 2020, 44, 1113-1125. [CrossRef]

327. da Silva-Maia, J.K.; Batista, A.G.; Correa, L.C.; Lima, G.C.; Bogusz Junior, S.; Maróstica Junior, M.R. Aqueous extract of berry (Plinia jaboticaba) byproduct modulates gut microbiota and maintains the balance on antioxidant defense system in rats. J. Food Biochem. 2019, 4, e12705. [CrossRef]

328. Huang, H.; Belwal, T.; Jiang, L.; Hu, J.; Limwachiranon, J.; Li, L.; Ren, G.; Zhang, X.; Luo, Z. Valorization of lotus byproduct (Receptaculum Nelumbinis) under green extraction condition. Food Bioprod. Process. 2019, 115, 110-117. [CrossRef]

329. Campone, L.; Celano, R.; Piccinelli, A.L.; Pagano, I.; Carabetta, S.; Sanzo, R.D.; Russo, M.; Ibañez, E.; Cifuentes, A.; Rastrelli, L. Response surface methodology to optimize supercritical carbon dioxide/co-solvent extraction of brown onion skin by-product as source of nutraceutical compounds. Food Chem. 2018, 269, 495-502. [CrossRef] [PubMed]

330. Frum, A.; Georgescu, C.; Gligor, F.G.; Lengyel, E.; Stegarus, D.I.; Dobrea, C.M.; Tita, O. Identification and quantification of phenolic compounds from red grape pomace. Sci. Stud. Res. Chem. ChemEng. Biotech. Food Ind. 2018, 19, 45-52.

331. Valadez-Carmona, L.; Plazola-Jacinto, C.P.; Hernández-Ortega, M.; Hernández-Navarro, M.D.; Villarreal, F.; NecoecheaMondragón, H.; Ortiz-Moreno, A.; Ceballos-Reyes, G. Effects of microwaves, hot air and freeze-drying on the phenolic compounds, antioxidant capacity, enzyme activity and microstructure of cacao pod husks (Theobroma cacao L.). Innov. Food Sci. Emerg. Technol. 2017, 41, 378-386. [CrossRef]

332. Jelley, R.E.; Herbst-Johnstone, M.; Klaere, S.; Pilkington, L.I.; Grose, C.; Martin, D.; Barker, D.; Fedrizzi, B. Optimization of Ecofriendly Extraction of Bioactive Monomeric Phenolics and Useful Flavor Precursors from Grape Waste. ACS Sustain. Chem. Eng. 2016, 4, 5060-5067. [CrossRef]

333. Ribeiro, L.F.; Ribani, R.H.; Francisco, T.M.G.; Soares, A.A.; Pontarolo, R.; Haminiuk, C.W.I. Profile of bioactive compounds from grape pomace (Vitis vinifera and Vitis labrusca) by spectrophotometric, chromatographic and spectral analyses. J. Chromatogr. B Analyt. Technol. Biomed. Life Sci. 2015, 1007, 72-80. [CrossRef] [PubMed]

334. Ekman, A.; Campos, M.; Lindahl, S.; Co, M.; Börjesson, P.; Karlsson, E.N.; Turner, C. Bioresource utilisation by sustainable technologies in new value-added biorefinery concepts-Two case studies from food and forest industry. J. Cleaner Prod. 2013, 57, 46-58. [CrossRef]

335. Bakowska-Barczak, A.M.; Schieber, A.; Kolodziejczyk, P. Characterization of Canadian black currant (Ribes nigrum L.) seed oils and residues. J. Agr. Food Chem. 2009, 57, 11528-11536. [CrossRef] [PubMed] 